\title{
Propagation of radiosonde pressure sensor errors to ozonesonde measurements
}

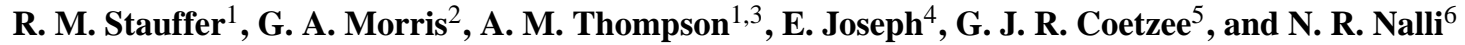 \\ ${ }^{1}$ Department of Meteorology, The Pennsylvania State University, University Park, Pennsylvania, USA \\ ${ }^{2}$ Department of Physics and Astronomy, Valparaiso University, Valparaiso, Indiana, USA \\ ${ }^{3}$ NASA/Goddard Space Flight Center, Greenbelt, Maryland, USA \\ ${ }^{4}$ Department of Physics and Astronomy, Howard University, Washington, DC, USA \\ ${ }^{5}$ South African Weather Service, Pretoria, South Africa \\ ${ }^{6}$ I.M. Systems Group, Inc., NOAA/NESDIS/STAR, College Park, Maryland, USA
}

Correspondence to: R. M. Stauffer (rms5539@psu.edu)

Received: 26 July 2013 - Published in Atmos. Meas. Tech. Discuss.: 26 August 2013

Revised: 20 November 2013 - Accepted: 27 November 2013 - Published: 10 January 2014

\begin{abstract}
Several previous studies highlight pressure (or equivalently, pressure altitude) discrepancies between the radiosonde pressure sensor and that derived from a GPS flown with the radiosonde. The offsets vary during the ascent both in absolute and percent pressure differences. To investigate this problem further, a total of 731 radiosonde/ozonesonde launches from the Southern Hemisphere subtropics to northern mid-latitudes are considered, with launches between 2005 and 2013 from both longer term and campaign-based intensive stations. Five series of radiosondes from two manufacturers (International Met Systems: iMet, iMet-P, iMet-S, and Vaisala: RS80-15N and RS92-SGP) are analyzed to determine the magnitude of the pressure offset. Additionally, electrochemical concentration cell (ECC) ozonesondes from three manufacturers (Science Pump Corporation; SPC and ENSCI/Droplet Measurement Technologies; DMT) are analyzed to quantify the effects these offsets have on the calculation of ECC ozone $\left(\mathrm{O}_{3}\right)$ mixing ratio profiles $\left(\mathrm{O}_{3 \mathrm{MR}}\right)$ from the ozonesonde-measured partial pressure. Approximately half of all offsets are $> \pm 0.6 \mathrm{hPa}$ in the free troposphere, with nearly a third $> \pm 1.0 \mathrm{hPa}$ at $26 \mathrm{~km}$, where the $1.0 \mathrm{hPa}$ error represents $\sim 5 \%$ of the total atmospheric pressure. Pressure offsets have negligible effects on $\mathrm{O}_{3 \mathrm{MR}}$ below $20 \mathrm{~km}$ (96\% of launches lie within $\pm 5 \% \mathrm{O}_{3 \mathrm{MR}}$ error at $20 \mathrm{~km})$. Ozone mixing ratio errors above $10 \mathrm{hPa}(\sim 30 \mathrm{~km})$, can approach greater than $\pm 10 \%$ ( $>25 \%$ of launches that reach $30 \mathrm{~km}$ exceed this threshold). These errors cause disagreement between the integrated ozonesonde-only column
\end{abstract}

$\mathrm{O}_{3}$ from the GPS and radiosonde pressure profile by an average of +6.5 DU. Comparisons of total column $\mathrm{O}_{3}$ between the GPS and radiosonde pressure profiles yield average differences of $+1.1 \mathrm{DU}$ when the $\mathrm{O}_{3}$ is integrated to burst with addition of the McPeters and Labow (2012) above-burst $\mathrm{O}_{3}$ column climatology. Total column differences are reduced to an average of $-0.5 \mathrm{DU}$ when the $\mathrm{O}_{3}$ profile is integrated to $10 \mathrm{hPa}$ with subsequent addition of the $\mathrm{O}_{3}$ climatology above $10 \mathrm{hPa}$. The RS92 radiosondes are superior in performance compared to other radiosondes, with average $26 \mathrm{~km}$ errors of $-0.12 \mathrm{hPa}$ or $+0.61 \% \mathrm{O}_{3 \mathrm{MR}}$ error. iMet-P radiosondes had average $26 \mathrm{~km}$ errors of $-1.95 \mathrm{hPa}$ or $+8.75 \% \mathrm{O}_{3 \mathrm{MR}}$ error. Based on our analysis, we suggest that ozonesondes always be coupled with a GPS-enabled radiosonde and that pressure-dependent variables, such as $\mathrm{O}_{3 \mathrm{MR}}$, be recalculated/reprocessed using the GPS-measured altitude, especially when $26 \mathrm{~km}$ pressure offsets exceed $\pm 1.0 \mathrm{hPa} / \pm 5 \%$.

\section{Introduction}

A number of fundamental intercomparison studies of radiosonde (e.g., Nash et al., 2006, 2011; da Silveira et al., 2006) and ozonesonde (e.g., Smit et al., 2007; Deshler et al., 2008) instrument performance have appeared within the past two decades. Radiosonde investigations have focused on comparisons of instrument type with respect to temperature (Gaffen, 1994; Gaffen et al., 1999; Steinbrecht et 
al., 2008; Sun et al., 2010), humidity (Vömel et al., 2007; Yoneyama et al., 2008; Miloshevich et al., 2006; Sun et al., 2010) and pressure (De Muer and De Backer, 1992; Inai et al., 2009; Hurst et al., 2011) measurements and typically have been associated with the adoption of new sonde models. The performance of electrochemical concentration cell (ECC) ozonesonde instruments, of which there have been three manufacturers since the 1970s, has been compared with various compositions of sensing solution type in laboratory conditions (Smit and Kley, 1998; Smit et al., 2007; Smit and Berg, 2011), and field conditions (Komhyr et al., 1995a, b; Thompson et al., 2007; Deshler et al., 2008). The discrepancies among the ozonesonde instrument-sensing-solution combinations are $\sim 5-15 \%$ relative to an absolute $\mathrm{O}_{3}$ measurement, depending on ECC manufacturer, and are pressure (and thus, altitude) dependent. The $\mathrm{O}_{3}$ community has made many attempts to homogenize standard operational procedures (Deshler, 2012; WMO, 2013) for station pre-flight preparations and intercomparison of different ECC cells, so some of the performance characteristics of the ozonesonde prior to launch are well understood. At present, the global ozonesonde community is reprocessing thousands of $\mathrm{O}_{3}$ profiles from dozens of stations to produce a more accurate profile data set for trend analysis (Ozonesonde Data Quality Assessment, O3S-DQA; Smit et al., 2012). In this effort, the pressure measured by the radiosonde to which the $\mathrm{O}_{3}$ partial pressure is referenced, has been taken as free of biases.

The relatively recent widespread use of GPS-enabled radiosondes has shown that pressure sensors often differ from the pressure derived from the GPS data. These errors propagate to errors in the calculated $\mathrm{O}_{3}$ mixing ratio $\left(\mathrm{O}_{3 \mathrm{MR}}\right)$.

\subsection{Efforts to quantify radiosonde errors and biases}

Numerous intercomparison studies investigate biases in the pressure, temperature, humidity and GPS measurements amongst various radiosonde types. da Silveira et al. (2006) launched five types of GPS-enabled radiosondes in groups to analyze GPS measurements in addition to meteorological measurements. They found the reproducibility and comparisons of GPS altitude in the stratosphere were within $\pm 20 \mathrm{~m}$. Similar results were obtained by Nash et al. (2006, 2011), who, in two different studies, found pressure sensors to be superfluous based on excellent performance of GPS radiosondes. Hurst et al. (2011) compared RS92 and iMet pressure measurements and found that paired RS92 radiosondes all compared to within $\pm 0.3 \mathrm{hPa}$ in the stratosphere and that iMet radiosondes averaged approximately $0.8 \mathrm{hPa}$ lower than the RS92s between $25-30 \mathrm{~km}$, an error of $>5 \%$. Inai et al. (2009) studied individual RS80 radiosonde launches to compare pressure derived from GPS measurements with the radiosonde pressure sensor and found pressure sensor biases of $-0.5 \mathrm{hPa}$ above $20 \mathrm{~km}$. These pressure errors need to be considered in the context of $\mathrm{O}_{3 \mathrm{MR}}$ measurements and total column $\mathrm{O}_{3}$ integration.
Lately, radiosonde manufacturers (e.g., Lockheed Martin Sippican, Inc., GPS Mark II Microsonde) have been producing radiosondes without pressure sensors, relying on GPS altitude, temperature, and humidity measurements and the hypsometric equation to derive pressure data. This same technique is used in this study and will be described below.

\subsection{Importance of accurate $\mathrm{O}_{3}$ measurements}

The importance of long-term, accurate $\mathrm{O}_{3}$ profile records is well documented in climate reports (IPCC, 2007), $\mathrm{O}_{3}$ assessment reports (WMO, 2011), and numerous studies of trends in tropospheric (Logan et al., 1994; Logan et al., 1999, 2012; IPCC, 2007), stratospheric (Miller et al., 1995; Froidevaux et al., 1996; Liu et al., 2006; Rault and Taha, 2007; Jiang et al., 2007; Kroon et al., 2011) and total column O 3 (Thompson et al., 2003, Osterman et al., 2008). Furthermore, ozonesondes provide the highest vertical resolution $(\sim 100 \mathrm{~m}) \mathrm{O}_{3}$ measurements from the surface to over $30 \mathrm{~km}$. For this reason, the satellite remote-sensing community continues to use ozonesonde profile data for validation and improvement of $\mathrm{O}_{3}$ profile retrievals (e.g., Nalli et al., 2013). The absolute accuracy of radiosonde measured pressure profiles themselves also has ramifications in the validation of satellite-derived pressure-profile Environmental Data Records (EDRs; Nalli et al., 2013).

Biases in $\mathrm{O}_{3}$ measurements from the use of several different types of ECC ozonesonde manufacturers, as well as different potassium iodide sensing solution strengths and sonde preparation techniques have made the homogenization of the historical ozonesonde record a necessity. The goals of the homogenization process performed through collaborative activities from WMO's O3S-DQA (Smit et al., 2012) and SI2N (this special issue) are to compile the highest accuracy $\mathrm{O}_{3}$ profile records for more robust trend studies and satellite comparisons (Deshler, 2012). With the ongoing reprocessing of ozonesonde data, it is vital to identify every potential bias or error in the $\mathrm{O}_{3}$ measurements. A goal of this paper is to contribute to a consensus-based recommendation on the handling of these radiosonde errors. Note, however that the data we present here and recommendations made apply only to radiosondes launched in the GPS era.

In the present investigation a series of 624 ozonesonderadiosonde instrument packages and 107 RS92-SGP radiosondes flown solo have been analyzed. In this paper, we address the following questions:

1. What are the statistical characteristics for pressure differences ("offsets") between the pressure sensor and that derived from the GPS? How do the offsets vary as a function of pressure (altitude)?

2. How do the offsets vary between radiosonde models? In this study, we analyze the RS92-SGP, three versions of International Met Systems (iMet) radiosondes, all of which have GPS units integrated into the radiosonde 
hardware, and the RS80-15N flown with a separate Garmin GPS unit attached inside the ozonesonde styrofoam box.

3. In addition to pressure offsets, some of the radiosondes demonstrate highly variable pressure measurements during ascent, especially in the stratosphere. What are the statistical characteristics of this variability?

4. How do the radiosonde pressure offsets propagate to the $\mathrm{O}_{3}$ profiles? How is integrated total $\mathrm{O}_{3}$ to either the balloon burst altitude or a pressure cut off (e.g., $\sim 11 \mathrm{hPa} / \sim 30 \mathrm{~km}$, as recommended in Dobson, 1973 or $10 \mathrm{hPa}$, as utilized in Thompson et al., 2003, 2007), and an extrapolated add-on determined from a climatology like McPeters and Labow (2012) affected?

The soundings were taken in the 2005-2013 period in a range of locations from the northern mid-latitudes through the subtropics and tropics to southern subtropics (Table 1).

\section{Methodology}

\subsection{Site and instrument descriptions}

A total of 731 radiosondes were analyzed for this study, with ozonesonde/radiosonde pairs accounting for 624 of those profiles. Our analysis includes data from twelve different launch sites (including two simultaneously operated, closely located sites in Houston, TX) launching five types of radiosondes, and spanning the years 2005-2013 (Table 1). The locations range from the southern subtropics (Irene, South Africa) to the northern mid-latitudes (Sapporo, Japan) with every month of the year represented. Stations include both those making regular ozonesonde launches (Irene, Houston, Beltsville) and those making intensive launches for specific campaigns (see Table 2 for campaign details), as well as other profiling missions at other sites.

Two radiosonde types from Vaisala (Vantaa, Finland; RS80-15N, RS92-SGP; herein RS80 and RS92) and three from International Met Systems (Grand Rapids, MI, USA; iMet, iMet-P, iMet-S) were launched at the various locations. Analyses are presented for each radiosonde type. The number of launches of each radiosonde type and the manufacturer-quoted pressure accuracies/uncertainties are given in Table 3. International Met Systems uses a piezoresistive silicon device to measure pressure and quotes only one pressure accuracy throughout the manufacturing of their radiosondes from 2009-2013. The analyses are still presented by each series type (based on serial numbers that are, in general, temporally partitioned) to determine any differences throughout the evolution of iMet radiosonde production. The RS92 radiosondes received a significant pressure sensor upgrade from the RS80s, moving from an aneroid capacitor, which is observed to have a low bias in the stratosphere
(Steinbrecht et al., 2008), to a more accurate solid-state silicon barocap sensor. Note that the quoted Vaisala pressure accuracies are valid only if a ground check with an independent surface pressure measurement and calibration are performed prior to launch. The RS92 radiosondes used in this study underwent this check.

\subsection{Ozonesonde measurements}

Each of the Science Pump Corporation (SPC) and ENSCI/Droplet Measurement Technologies (DMT) ozonesondes in this study operate using the electrochemical concentration cell (ECC; Komhyr, 1969) technique where ambient air is bubbled through a potassium iodide solution. The subsequent reactions generate two electrons per $\mathrm{O}_{3}$ molecule, so the current measured through an attached circuit board is converted to $\mathrm{O}_{3}$ partial pressure $\left(p_{\mathrm{O} 3}\right)$ via this equation:

$p_{\mathrm{O} 3}=0.043085 \cdot \frac{T_{\mathrm{p}}}{(\varepsilon \times F)} \cdot\left(I_{\mathrm{M}}-I_{\mathrm{B}}\right)$,

where the constant 0.043085 is derived from the ratio between the gas constant $R$ and the Faraday constant, $T_{\mathrm{p}}$ the measured temperature of the ozonesonde pump, $\varepsilon$ the pump efficiency, $F$ the volumetric flow rate through the pump, $I_{\mathrm{M}}$ the measured electrical cell current, and $I_{\mathrm{B}}$ the background cell current quantified in lab testing prior to launch (WMO, 2013).

Since $\mathrm{O}_{3 \mathrm{MR}}$ is calculated from $p_{\mathrm{O} 3}$ and total air pressure, $p_{\text {air: }}$ :

$O_{3 \mathrm{MR}}=p_{\mathrm{O} 3} / p_{\text {air }}$,

any bias or error in the radiosonde pressure measurement introduces error in $\mathrm{O}_{3 \mathrm{MR}}$. The $p_{\mathrm{O} 3}$ measurements have typical tropospheric accuracies on the order of -7 to $+17 \%$, improving to $\pm 5 \%$ in the low to mid-stratosphere with decreasing accuracy above $10 \mathrm{hPa}$, provided standardized and accepted ozonesonde conditioning and launch procedures are followed (Komhyr et al., 1995b; WMO, 2013).

\subsection{Calculation of GPS pressure}

The pressure altitude reported by the radiosonde is given in geopotential altitude $(Z)$, using standard gravity $\left(g_{0}=\right.$ $9.80665 \mathrm{~m} \mathrm{~s}^{-2}$ ). Conversely, the GPS altitude is reported as a geometric altitude $(H)$, and the latitude $\left(g_{\phi} \approx 9.78\right.$ $9.83 \mathrm{~m} \mathrm{~s}^{-2}$ ) and altitude-dependent gravity is used to calculate pressure. The equation for gravity with latitude $(\phi)$ is estimated from the WGS-84 ellipsoid (National Imagery and Mapping Agency, 2000, p. 42):

$$
g_{\phi}=9.7803267714 \cdot \frac{1+0.00193185138639 \sin ^{2} \phi}{\sqrt{1-0.00669437999013 \sin ^{2} \phi}} .
$$

The gravity with altitude is then given by

$g_{\phi, H}=g_{\phi}+\left[\frac{G m_{\mathrm{E}}}{\left(r_{\mathrm{E}}+H\right)^{2}}-\frac{G m_{\mathrm{E}}}{r_{\mathrm{E}}^{2}}\right]$, 
Table 1. Balloon launch locations with latitude/longitude coordinates, number of launches, radiosonde types used and lengths of records used in this study.

\begin{tabular}{|c|c|c|c|c|}
\hline Location & Lat/Lon & Launches & Radiosonde types & Length of record \\
\hline Irene, South Africa & $-25.91^{\circ} / 28.21^{\circ}$ & 28 & RS92-SGP & 20 Feb 2012-8 May 2013 \\
\hline Las Tablas, Panama & $7.75^{\circ} /-80.25^{\circ}$ & 23 & RS80-15N & 13 Jul 2007-9 Aug 2007 \\
\hline Houston, Texas (Two Locations) & $\begin{array}{l}29.72^{\circ} /-95.34^{\circ} \text { and } \\
30.03^{\circ} /-94.08^{\circ}\end{array}$ & 275 & RS80-15N, iMet, iMet-P, iMet-S & 20 Sep 2005-26 Jan 2013 \\
\hline $\begin{array}{l}\text { Ronald H. Brown R/V, Gulf of } \\
\text { Mexico }\end{array}$ & $\begin{array}{l}24.8^{\circ} \text { to } 29.7^{\circ} /-94.7^{\circ} \\
\text { to }-83.5^{\circ}\end{array}$ & $\begin{array}{l}37,107 \\
\text { radiosonde } \\
\text { only }\end{array}$ & RS92-SGP & 27 Jul 2006-11 Sep 2006 \\
\hline $\begin{array}{l}\text { Ronald H. Brown R/V, AEROSE } \\
\text { Expeditions }\end{array}$ & $\begin{array}{l}-23.5^{\circ} \text { to } 31.8^{\circ} /-76.0^{\circ} \\
\text { to }-5.9^{\circ}\end{array}$ & 69 & RS92-SGP & 11 May 2007-22 May 2010 \\
\hline Idabel, Oklahoma & $33.89^{\circ} /-94.75^{\circ}$ & 57 & iMet, iMet-P, iMet-S & 19 Jul 2010-6 Oct 2012 \\
\hline Porterville, California & $36.03^{\circ} /-119.05^{\circ}$ & 25 & iMet, iMet-S & 16 Jan 2013-6 Feb 2013 \\
\hline Beltsville, Maryland & $39.05^{\circ} /-76.88^{\circ}$ & 16 & RS92-SGP & 27 Jun 2007-7 Aug 2007 \\
\hline Edgewood, Maryland & $39.41^{\circ} /-76.30^{\circ}$ & 36 & iMet-S & 28 Jun 2011-30 Jul 2011 \\
\hline Valparaiso, Indiana & $41.46^{\circ} /-87.04^{\circ}$ & 31 & RS80-15N & 19 Apr 2006-3 Nov 2007 \\
\hline Sapporo, Japan & $43.07^{\circ} / 141.35^{\circ}$ & 27 & RS80-15N & 6 Aug 2008-4 Sep 2009 \\
\hline
\end{tabular}

Table 2. List of campaigns, their respective locations, websites and radiosonde types launched.

\begin{tabular}{|c|c|c|c|c|}
\hline Campaign & Location(s) & Website & $\begin{array}{l}\text { Radiosonde } \\
\text { types }\end{array}$ & Dates available \\
\hline $\begin{array}{l}\mathrm{TC}^{4} \text { : Tropical Composition, Cloud, and } \\
\text { Climate Coupling }\end{array}$ & Las Tablas, Panama & $\begin{array}{l}\text { http://www.nasa.gov/ } \\
\text { mission_pages/TC4/ }\end{array}$ & RS80-15N & Jul-Aug 2007 \\
\hline $\begin{array}{l}\text { IONS-06: INTEX-B Ozonesonde Network } \\
\text { Study } 2006\end{array}$ & $\begin{array}{l}\text { Houston, TX, Ronald H. Brown } \\
\text { R/V }\end{array}$ & $\begin{array}{l}\text { http://croc.gsfc.nasa. } \\
\text { gov/intexb/ions06.html }\end{array}$ & $\begin{array}{l}\text { RS80-15N, } \\
\text { RS92-SGP }\end{array}$ & Mar-May, Aug-Sep 2006 \\
\hline $\begin{array}{l}\text { DISCOVER-AQ: Deriving Information on Sur- } \\
\text { face Conditions from Column and Vertically } \\
\text { Resolved Observations Relevant to Air Quality }\end{array}$ & $\begin{array}{l}\text { Edgewood, MD, Porterville, } \\
\text { CA }\end{array}$ & $\begin{array}{l}\text { http://www.nasa. } \\
\text { gov/mission_pages/ } \\
\text { discover-aq/index.html }\end{array}$ & iMet, iMet-S & Jul 2011, Jan-Feb 2013 \\
\hline $\begin{array}{l}\text { AEROSE: NOAA Aerosols and Ocean Science } \\
\text { Expeditions }\end{array}$ & Ronald H. Brown $\mathrm{R} / \mathrm{V}$ & http://aerose.org/ & RS92-SGP & May 2007-May 2010 \\
\hline TOPP: Tropospheric Ozone Pollution Project & $\begin{array}{l}\text { Houston, TX, Idabel, OK, Val- } \\
\text { paraiso, IN, Sapporo, Japan }\end{array}$ & $\begin{array}{l}\text { http://physics.valpo. } \\
\text { edu/ozone/index.html }\end{array}$ & $\begin{array}{l}\text { RS80-15N, } \\
\text { iMet, iMet-P, } \\
\text { iMet-S }\end{array}$ & Sep 2005-Jan 2013 \\
\hline
\end{tabular}

where $g_{\phi}$ is the surface gravity at a given location, $G$ the gravitational constant $\left(6.67428 \times 10^{-11} \mathrm{~N} \mathrm{~m}^{2} \mathrm{~kg}^{-2}\right), m_{\mathrm{E}}$ the mass of Earth $\left(5.9736 \times 10^{24} \mathrm{~kg}\right), r_{\mathrm{E}}$ the average radius of Earth $\left(6.371 \times 10^{6} \mathrm{~m}\right)$, and $H$ the GPS altitude from the radiosonde.

This process is the reverse of obtaining a geopotential altitude from the radiosonde pressure measurements, but with a geometric altitude. We note that the reported GPS altitude is actually an ellipsoidal altitude, though the difference between that and altitude AMSL (geoidal altitude; National Imagery and Mapping Agency, 2000, p. 68) is reconciled with the input of the station AMSL altitude as the initial GPS altitude prior to launch. Surface pressure from the radiosonde (often set at the launch site from a high-precision barometer) is used to initialize the GPS pressure calculation from the hypsometric equation:

$p_{\mathrm{GPS} i}=p_{\mathrm{GPS} i-1} \exp \left[-\frac{g_{\phi, H} \Delta H}{R_{\mathrm{d}} T_{\mathrm{vavg}}}\right]$.

Here, $p_{\mathrm{GPS}}$, is the pressure calculated from $g_{\phi, H}$, the latitude and altitude-dependent gravity, $\Delta H$, the change in geometric GPS altitude from consecutive measurements, $R_{\mathrm{d}}$, the specific gas constant for dry air $\left(287.05 \mathrm{~J} \mathrm{~kg}^{-1} \mathrm{~K}^{-1}\right)$, and $T_{\text {vavg }}$, the average virtual temperature of the consecutive measurements. Calculating pressure in iterative fashion from measurement to measurement throughout the profile reduces the error that use of a standard atmosphere or scale height would introduce. Since the uncertainty in the GPS altitude is small (Nash et al., 2006, 2011), usually within $\pm 20 \mathrm{~m}$ (Vaisala RS92 technical specifications testing) to $\pm 30 \mathrm{~m}$ (iMet radiosonde $2 \sigma$ error specifications), the uncertainty resulting from GPS altitude measurements in the calculated $p_{\text {GPS }}$ will be negligible in the stratosphere. An additional source of uncertainty in $p_{\text {GPS }}$ results from errors and biases in radiosonde temperature and humidity measurements (Richner and Viatte, 1995; Hurst et al., 2011). Large systematic biases in radiosonde temperature measurements can cause some errors in the calculated $p_{\text {GPS }}$ profile. However, the characteristic pressure errors resulting from temperature biases bear no resemblance to the errors seen in this paper - therefore we rule out this factor as the cause of the pressure offset. The $p_{\mathrm{GPS}}$ calculation assumes that the atmosphere is in hydrostatic balance with pressure dependence only in the vertical and with negligible changes horizontally 


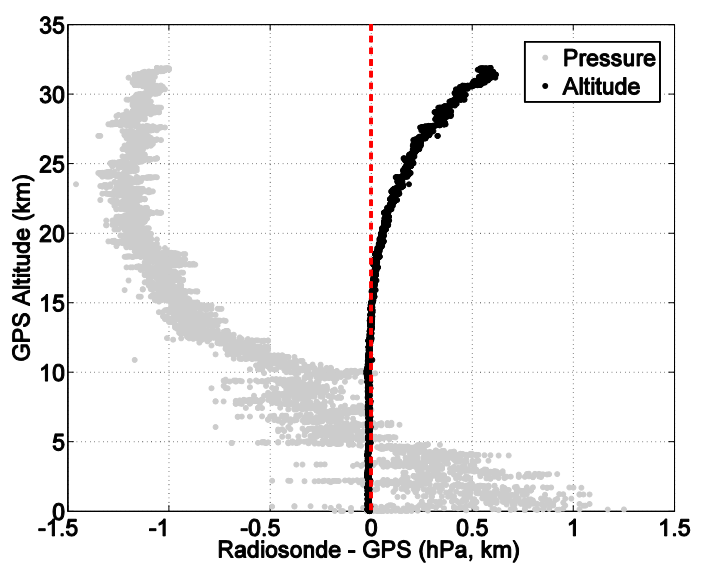

Fig. 1. Edgewood, MD iMet-S profile from 14 July, 2011 of GPS and pressure altitude differences (black), and pressure differences after recalculation of pressure data from GPS measurements (grey). The red dashed line marks the zero line for reference. The median $26 \mathrm{~km}$ pressure offset for this launch is $-1.17 \mathrm{hPa}$.

and in time. The radiosonde makes the same assumption when deriving a geopotential altitude from the pressure measurements through use of the hypsometric equation.

An example of the differences in radiosonde pressure (herein $p$ ) and $p_{\text {GPS }}$ (treated as the reference), as well as the pressure altitude and GPS altitude differences, are shown in Fig. 1. Large differences, on the order of hundreds (and sometimes thousands) of meters, between pressure altitude and GPS altitude are an indication of systematic errors in reported pressures. For the remainder of this paper, we define the pressure offset to be $p-p_{\mathrm{GPS}}$.

Variability in the pressure offset appears in the lower troposphere since a difference of just a few meters between the GPS and the pressure altitude can cause several tenths of $1 \mathrm{hPa}$ difference between the calculated and measured pressures. The noise in the pressure offset stabilizes in the stratosphere and tends to remain somewhat constant until balloon burst.

\subsection{Recalculation of pressure-dependent data}

Using the pressure calculated from the GPS measurements, any pressure-dependent variables can be recalculated and compared to the original measurements. In addition to the reported altitude and pressure differences between the GPS and radiosonde measurements, we examine the effects on the $\mathrm{O}_{3 \mathrm{MR}}$ and total column $\mathrm{O}_{3}$. (Note that the pressure corrections implemented here also result in a need to recalculate potential temperature and, to a lesser extent, water vapor mixing ratio, but we do not discuss these modifications here). We choose to examine $\mathrm{O}_{3 \mathrm{MR}}$ rather than $p_{\mathrm{O} 3}$ so we can describe statistics on the differences between "coincident" measurements on a single GPS altitude, that is, the original $\mathrm{O}_{3 \mathrm{MR}}$ and the GPS-pressure derived and recalculated $\mathrm{O}_{3 \mathrm{MR}}$. The $p_{\mathrm{O} 3}$ is

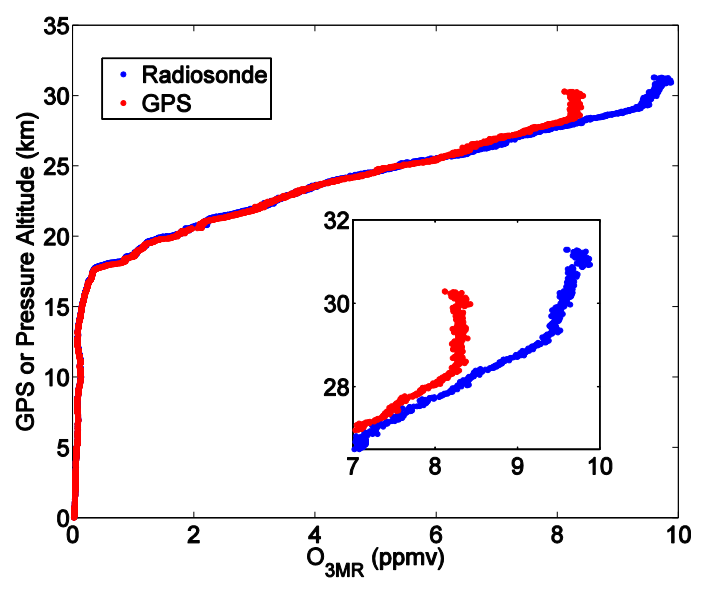

Fig. 2. Sapporo, Japan, RS80 profile from 19 August 2008 showing original pressure (blue) and recalculated GPS pressure (red) $\mathrm{O}_{3 \mathrm{MR}}$ profiles. The inset figure is the same profile, zoomed in to highlight $\mathrm{O}_{3}$ differences in the stratosphere. The median $26 \mathrm{~km}$ pressure offset for this launch is $-1.94 \mathrm{hPa}$.

not dependent on ambient pressure (except for minor pump efficiency corrections) so coincident measurements will not change in magnitude, and only an altitude shift in the profile will be evident.

The recalculation of $\mathrm{O}_{3 \mathrm{MR}}$ causes differences in both the $\mathrm{O}_{3}$ magnitude and profile shape, particularly above $26 \mathrm{~km}$ and near the burst altitude (Fig. 2). Depending on the severity of the pressure offset, $\mathrm{O}_{3 \mathrm{MR}}$ errors can approach $\pm 1-2$ ppmv (parts per million by volume; $\pm 10-20 \%$ error) or greater in the stratosphere in the heart of the ozone layer. Differences between GPS altitude and pressure altitude can cause the apparent $\mathrm{O}_{3 \mathrm{MR}}$ maximum to shift by as much as $\pm 2 \mathrm{~km}$, having further consequences for stratospheric satellite measurements and comparison/validation studies with ozonesondes.

We note that a pressure-dependent pump correction factor (PCF) is applied to $p_{\mathrm{O} 3}$ based on decreasing ozonesonde pump efficiency in the stratosphere, particularly above $25 \mathrm{~km}$ (Johnson et al., 2002). However, both the application of various PCFs in different processing software and the negligible $(\sim 0.5 \%$ difference in PCF between 20 and $18 \mathrm{hPa}$, near where statistics from this paper are presented) difference the PCF has between $p$ and $p_{\text {GPS }}$ profiles lead us to neglect this small correction. This effort to quantify pressure sensor errors is separate from and not a substitute for the PCF problem.

\section{Results}

The IONS-06 campaign (Table 2) in March-May and August-September 2006 provided an opportunity to compare coincident $\mathrm{O}_{3}$ profiles from the University of Houston Main Campus (UH) and the Ronald H. Brown (herein RHB), operated by NOAA to record profiles near the Houston Ship 


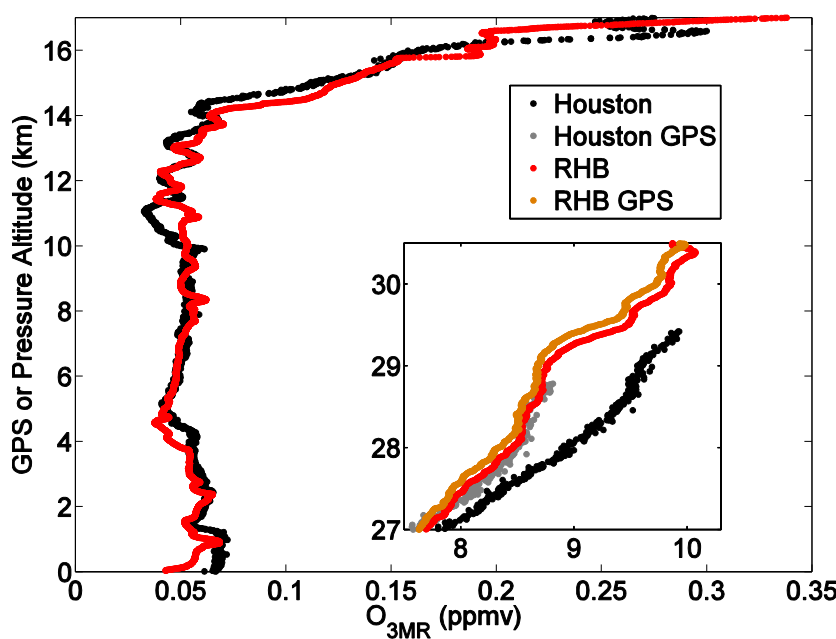

Fig. 3. Nearly coincident profiles from 30 August 2006 from the Ronald H. Brown (RS92), and Houston, TX (RS80). The original $\mathrm{O}_{3 \mathrm{MR}}$ profiles are shown in black (Houston) and red (RHB). The inset highlights improved stratospheric $\mathrm{O}_{3 \mathrm{MR}}$ agreement from the coincident RHB and Houston profiles after GPS reprocessing with the corrected profiles from $p_{\text {GPS }}$ shown in grey (Houston) and orange (RHB). The median $26 \mathrm{~km}$ pressure offsets for these launches are $-1.55 \mathrm{hPa}$ (Houston) and $0.00 \mathrm{hPa}$ (RHB).

Channel and in Galveston Bay. The comparisons allow us to test confidence in the $p_{\mathrm{GPS}}$ recalculation procedure, namely the reproducibility of stratospheric $\mathrm{O}_{3 \mathrm{MR}}$ using ozonesondes with different radiosonde types released closely in space and time. Nine such pairs occurred within $90 \mathrm{~min}$ of each other in IONS-06, with RHB launching RS92s and the UH site launching RS80s with a separate GPS unit attached. An example of one pair, $15 \mathrm{~min}$ and $77 \mathrm{~km}$ apart on $30 \mathrm{Au}-$ gust 2006, is shown in Fig. 3. The two profiles show similar tropospheric $\mathrm{O}_{3 \mathrm{MR}}$ with or without correcting the pressure offset (the $p$ and $p_{\text {GPS }}$ profiles are indistinguishable below $\sim 15 \mathrm{~km}$ ). The GPS corrected pressure, however, results in better agreement in stratospheric $\mathrm{O}_{3 \mathrm{MR}}$. Before correcting the pressure offset error, the mixing ratio differences between the two flights are greater than 1 ppmv near the UH balloon burst altitude (also note the altitude shift; Fig. 3). Those differences become markedly smaller to within $0.1-0.2 \mathrm{ppmv}$ after correction of both profiles using $p_{\mathrm{GPS}}$. Both the shift in the altitude and correction of the $\mathrm{O}_{3 \mathrm{MR}}$ contribute to this improved agreement.

\subsection{Statistical characteristics of the pressure offsets}

The median pressure offset for each $\mathrm{km}$ altitude bin (as in Hurst et al., 2011) from $1-30 \mathrm{~km}$ is shown in Fig. 4. The tight grouping of RS92 launches about the zero line is distinguishable, with considerably more spread near the top of the profiles measured with the other radiosonde types. Most individual radiosondes show less variable pressure offsets in the stratosphere, with the RS92s converging to zero. The iMet-P radiosondes exhibit a peculiar S-shape pressure offset peak around $5 \mathrm{~km}$ that is not understood (we can find no artifact or geophysical cause).

At $26 \mathrm{~km}$ (an altitude $69 \%$ of profiles reach, also chosen because $p \approx 20 \mathrm{hPa}$ at $26 \mathrm{~km}$ ), the iMet and RS80 radiosondes exhibit the most variable pressure offsets, with mean offsets of $-0.93 \mathrm{hPa}$ and $-1.01 \mathrm{hPa}$, respectively (see Table 4 for offset averages and percentiles). In Fig. 5, we see the radiosonde-measured pressure is consistently lower than $p_{\text {GPS }}$ for many of the radiosonde types, and nearly a third of all launches have an offset of $\pm 1.0 \mathrm{hPa}$ at $26 \mathrm{~km}$. The least variability is exhibited by the RS92s with only a $-0.12 \mathrm{hPa}$ average offset and just two outlier profiles beyond $\pm 1.0 \mathrm{hPa}$ at $26 \mathrm{~km}$.

Figure 6 shows pressure offsets at various altitudes as a function of the pressure offset at the burst altitude. The variance within the figure at different altitudes implies that the pressure offsets are not constant throughout most of the profile, and that a constant pressure correction cannot be applied to the entire profile. Only when the balloon reaches the stratosphere and around $15-20 \mathrm{~km}$ is a strong relationship evident. The tropospheric offsets appear much less constant than the stratospheric offsets, likely from variability in the GPS altitude and pressure sensor causing significant noise in the pressure offset below $10 \mathrm{~km}$. In the troposphere an offset of several hPa only represents a few percent of the total atmospheric pressure. At $20 \mathrm{~km}, 96 \%$ of all launches have less than $\pm 5 \%$ error. As a result, the true magnitude of the pressure offset and need for reprocessing cannot be determined until the balloon has reached the stratosphere (see Fig. A1 in Appendix A for altitude differences with pressure offset).

\section{$3.2 \mathrm{O}_{3 \mathrm{MR}}$ offsets}

Pressure offsets of only a few tenths of $1 \mathrm{hPa}$ are the equivalent of $5-10 \%$ errors in the total atmospheric pressure at the balloon burst altitude near $30 \mathrm{~km}$. This pressure offset error results in an error in the calculated $\mathrm{O}_{3 \mathrm{MR}}$ of the same magnitude (Fig. 7). We define the $\mathrm{O}_{3 \mathrm{MR}}$ offsets as $\left[\mathrm{O}_{3 \mathrm{MR}(p)^{-}}\right.$ $\left.\mathrm{O}_{3 \mathrm{MR}(\mathrm{GPS})}\right] / \mathrm{O}_{3 \mathrm{MR}(\mathrm{GPS})}$. Figure 7 demonstrates how a nearly constant stratospheric pressure offset results in an $\mathrm{O}_{3 \mathrm{MR}}$ offset that grows in magnitude with altitude, with many profiles beyond $\pm 10 \%$ error in the stratosphere. At such magnitudes, this error becomes a significant component of the overall error budget associated with $\mathrm{O}_{3}$ profile data from ozonesondes, and is beyond the intrinsic uncertainty of the $\mathrm{O}_{3}$ measurements.

Table 4 examines the $\mathrm{O}_{3 \mathrm{MR}}$ errors by radiosonde type. As with the pressure offsets, the most variable $\mathrm{O}_{3 \mathrm{MR}}$ percent offsets are displayed by the iMet and RS80 radiosondes with $+4.42 \%$ and $+4.75 \%$, at $26 \mathrm{~km}$, respectively. The iMet-P launches have an average offset at $26 \mathrm{~km}$ of $+8.75 \%$ that increases to $+15.9 \%$ by $30 \mathrm{~km}$, leading to an average error greater than 1 ppmv $\mathrm{O}_{3 \mathrm{MR}}$ by balloon burst. This large error 


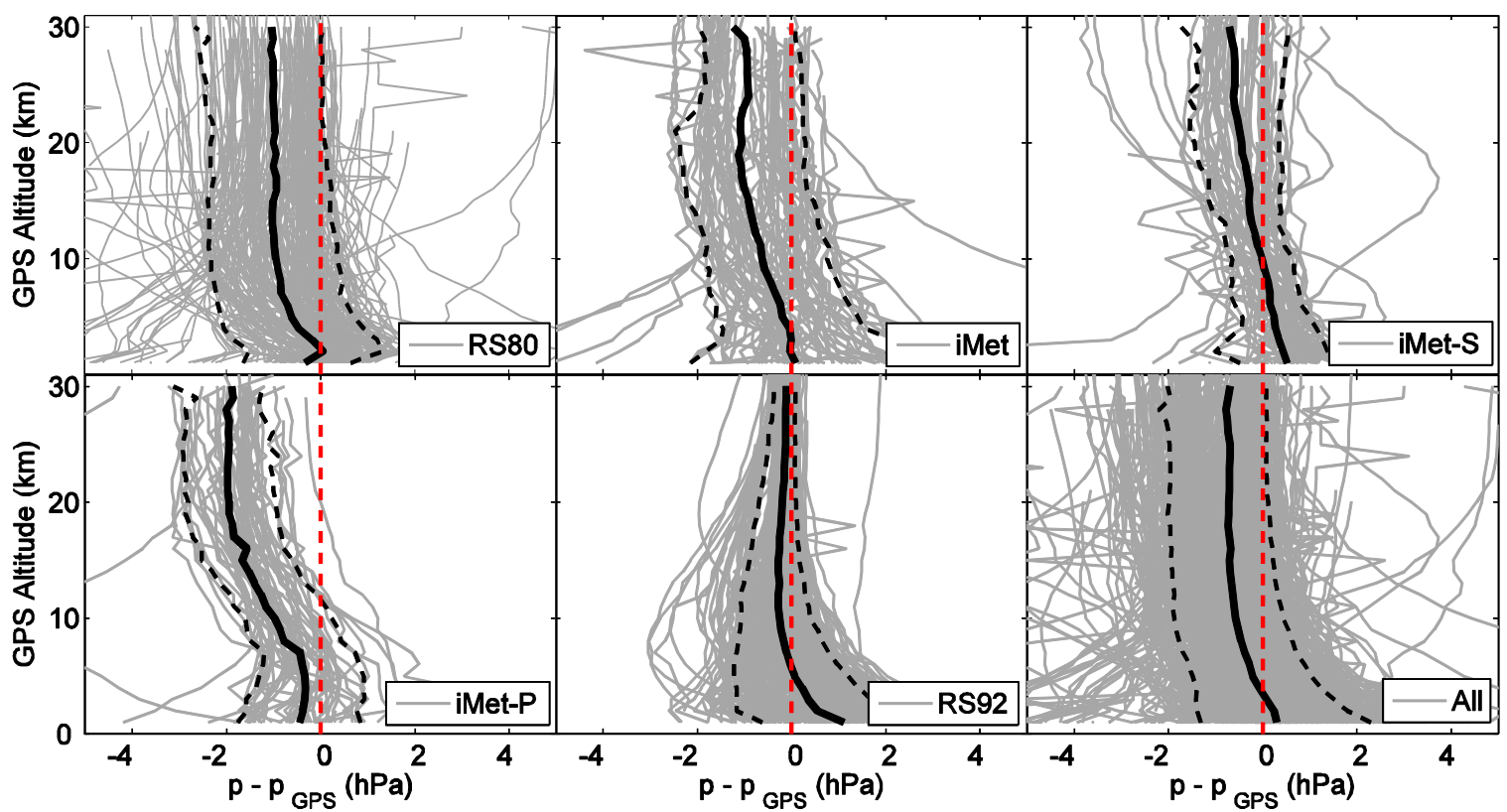

Fig. 4. Median pressure offset ( $p-p_{\mathrm{GPS}}$ ) for every $1 \mathrm{~km}$ altitude bin from 1-30 km for each radiosonde type (grey). Average offsets (black solid line) for each grouping of radiosondes are shown along with 10th and 90th percentiles (black dashes). A red dashed line marks the zero line for reference.

Table 3. Radiosonde types with number of launches, quoted pressure uncertainties/accuracies from the manufacturer, and dates of available launches. We note the various iMet series have had no appreciable changes to the pressure sensors, but are split in these analyses for convenience and ease of interpretation.

\begin{tabular}{lrll}
\hline Radiosonde type & Launches & Quoted pressure uncertainty/accuracy & Length of record \\
\hline iMet & 106 & $1070-400 \mathrm{hPa}: 1.8 \mathrm{hPa} / 400-4 \mathrm{hPa}: 0.5 \mathrm{hPa}^{1}$ & $28 \mathrm{May} 2009-6 \mathrm{Feb} 2013$ \\
iMet-P & 52 & $1070-400 \mathrm{hPa}: 1.8 \mathrm{hPa} / 400-4 \mathrm{hPa}: 0.5 \mathrm{hPa}^{1}$ & $23 \mathrm{Mar} 2012-26 \mathrm{Jan} 2013$ \\
iMet-S & 69 & $1070-400 \mathrm{hPa}: 1.8 \mathrm{hPa} / 400-4 \mathrm{hPa}: 0.5 \mathrm{hPa}^{1}$ & $5 \mathrm{Nov} 2009-16 \mathrm{Jan} 2013$ \\
RS80-15N & 247 & $1080-3 \mathrm{hPa}: 1.0 \mathrm{hPa}^{2}$ & 20 Sep 2005-23 Apr 2011 \\
RS92-SGP & 257 & $1080-100 \mathrm{hPa}: 0.5 \mathrm{hPa} / 100-3 \mathrm{hPa}: 0.3 \mathrm{hPa}^{2}$ & 27 Jul 2006-8 May 2013 \\
\hline
\end{tabular}

${ }^{1}$ The iMet values given are $2 \sigma$ accuracy limits. ${ }^{2}$ The RS80 and RS92 values given are $2 \sigma$ limits on sounding reproducibility, valid only after performing a ground check between the radiosonde and an independent measurement of surface pressure.

at $30 \mathrm{~km}$ is common; over a quarter of all launches that reach this altitude have $\mathrm{O}_{3 \mathrm{MR}}$ errors $> \pm 10 \%$.

Two distinct offset regimes are detected in the RS92s in Figs. 4 and 7, separable mainly by the launch sites Beltsville (one summer of data) and RHB near Galveston Bay (single campaign; see Figs. A2 and A3 in Appendix A for pressure and $\mathrm{O}_{3 \mathrm{MR}}$ offsets by launch site). The Beltsville pressure offsets lie slightly to the left of the zero line, and the RHB offsets straddle the zero line. Similar offset groupings are also observed in the campaign-based launches from Porterville, CA (iMet, only one iMet-S), Las Tablas, Panama (RS80) and the set of iMet-P sondes launched in the course of 10 months at Idabel and Houston. This suggests that particular "batches" of radiosondes, regardless of manufacturer/type, may have offsets that generally behave in similar manners. As a result, we caution against drawing conclusions about radiosonde types (particularly iMet-P radiosondes in this study) from offsets appearing in only one set or batch of sondes.

\subsection{Column ozone measurements}

Because the pressure offset affects both the apparent altitude and magnitude of $\mathrm{O}_{3 \mathrm{MR}}$, it is also of interest to compute the influence on total column amount of $\mathrm{O}_{3}$. Each ozonesonde that reached $26 \mathrm{~km}$ was integrated to obtain a column $\mathrm{O}_{3}$ amount in Dobson Units $(1 \mathrm{DU}=2.69 \times$ $10^{16}$ molecules $\mathrm{cm}^{-2}$ ) from both the original pressure profile and the recalculated $p_{\mathrm{GPS}}$ profile. As expected, considerable differences in the column integrated to the sonde burst altitude appear closely related to the pressure offset magnitude 
Table 4. Various pressure and $\mathrm{O}_{3}$ statistics separated by radiosonde type. All columns are presented in 10th percentile, mean and 90th percentile values. Values are reported as original pressure-profile data minus GPS-calculated pressure-profile data.

\begin{tabular}{lrrrrr}
\hline $\begin{array}{l}\text { Radiosonde } \\
\text { type }\end{array}$ & $\begin{array}{r}\text { Pressure } \\
\text { offset } \\
(\mathrm{hPa}, 26 \mathrm{~km})\end{array}$ & $\begin{array}{r}\mathrm{O}_{3 \mathrm{MR}} \\
\text { error } \\
(\%, 26 \mathrm{~km})\end{array}$ & $\begin{array}{r}\text { Sonde column } \\
\text { difference } \\
\text { (to burst, DU) }\end{array}$ & $\begin{array}{r}\text { Sonde column } \\
\text { difference } \\
\text { (to 10 hPa, DU) }\end{array}$ & $\begin{array}{r}\text { Total column } \\
\text { difference burst + add-on, DU) }\end{array}$ \\
\hline iMet & $-1.85,-0.93,0.22$ & $-0.88,4.42,8.94$ & $-0.1,11.2,19.4$ & $-0.1,3.5,7.0$ & $-1.0,3.8,7.8$ \\
(to 10 hPa + add-on, DU)
\end{tabular}

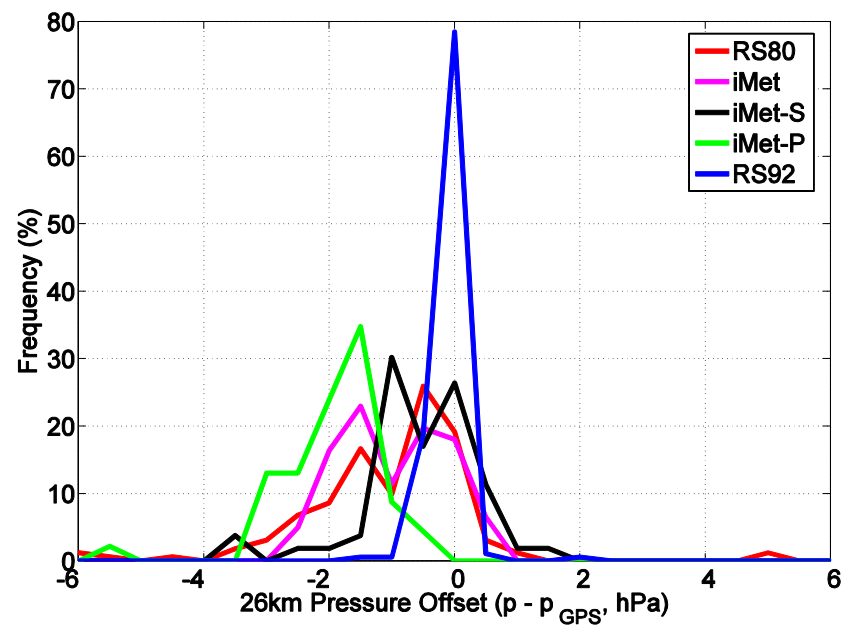

Fig. 5. Histogram of $26 \mathrm{~km}$ pressure offset in percent frequency by radiosonde type. Data are binned every $0.5 \mathrm{hPa}$. The various radiosonde types are identified by their respective colors.

in the stratosphere (Fig. 8a) - the radiosonde types that displayed the largest pressure and $\mathrm{O}_{3 \mathrm{MR}}$ offsets also present the largest sonde column offsets. The iMet, iMet-P and RS80 sonde-only column $\mathrm{O}_{3}$ is consistently $\sim 10 \mathrm{DU}$ higher than the $\mathrm{O}_{3}$ column computed using $p_{\text {GPS }}$ (Table 4 ; average column $\mathrm{O}_{3}$ difference from all sondes is $\left.+6.5 \mathrm{DU}\right)$.

Adding a typical $\mathrm{O}_{3}$ climatology (e.g., McPeters and Labow, 2012) above-balloon burst allows calculation of total $\mathrm{O}_{3}$ column abundance for both the original and pressurecorrected ozonesonde profiles. In this case, offsets are reduced to within a few DU (Fig. 9a). Note that sonde and/or satellite-based climatologies have become standard, replacing a constant mixing ratio assumption (McPeters et al., 1997, 2007; Thompson et al., 2003; McPeters and Labow, 2012; Morris et al., 2013). The constant mixing ratio assumption takes the $\mathrm{O}_{3}$ mixing ratio at balloon burst and extrapolates that value to the top of the atmosphere to provide the above-burst residual column. Thus, $\mathrm{O}_{3 \mathrm{MR}}$ errors such as those observed here will lead to significant errors in the residual and total column $\mathrm{O}_{3}$ if a constant mixing ratio method is used. The sonde-only $\mathrm{O}_{3}$ column discrepancies brought about by the differences in the balloon burst altitudes between the original and corrected pressure profiles are reconciled with the satellite climatological add-on above-balloon burst and comparison of the total column $\mathrm{O}_{3}$. The amount of total column offset is reduced to a mean offset within $3.8 \mathrm{DU}$ for every radiosonde type with the above-burst addition (Table 4), signifying that both the $\mathrm{O}_{3 \mathrm{MR}}$ error and altitude differences are contributing to total column discrepancies.

A common practice within the ozonesonde community is to cut off total column $\mathrm{O}_{3}$ integration at $10 \mathrm{hPa}$ (Thompson et al., 2003, 2007), rather than integrating the entire profile, and to apply a climatology such as that of McPeters and Labow (2012) to the remainder. This approach is employed and recommended for a variety of reasons including mitigation of increasing pump efficiency uncertainties with altitude in the stratosphere (Johnson et al., 2002) and the reduced accuracy of the $\mathrm{O}_{3}$ measurements above $10 \mathrm{hPa}$ (Komhyr et al., 1995b). The same technique was applied to the ozonesondes in this study to test if the sonde-only and total column $\mathrm{O}_{3}$ offset is reduced due to elimination of increasing $\mathrm{O}_{3 \mathrm{MR}}$ errors routinely observed above $10 \mathrm{hPa}$.

The $10 \mathrm{hPa}$ cut off considerably reduces the differences between the uncorrected and pressure offset corrected sondeonly columns for most radiosonde types. Exceptions are the iMet-P launches, which in our data set rarely reached $10 \mathrm{hPa}$ due to use of a smaller balloon (portions of the Houston and Idabel launches), and the RS92 profiles, which had little $\mathrm{O}_{3}$ column error to begin with. Since the iMet-P launches rarely reached $10 \mathrm{hPa}$, the entire balloon profile was integrated to the burst altitude, eliminating any effect this cut off would have had. With the exception of the iMet-P sondes, sonde-only column $\mathrm{O}_{3}$ average differences are reduced from a maximum of $11.2 \mathrm{DU}$ to within $3.5 \mathrm{DU}$ (Table 4 , Fig. 8b) with a $10 \mathrm{hPa}$ cut off. Considering the total column $\mathrm{O}_{3}$ with the $10 \mathrm{hPa}$ cut off and subsequent McPeters and Labow (2012) climatological add-on, the agreement between the uncorrected and corrected pressure $\mathrm{O}_{3}$ columns is further improved and most differences are essentially noise within the uncertainty of the total column integration from the ozonesonde. All radiosonde types agree to an average offset within -1.7 to $+0.8 \mathrm{DU}$, with the poorest agreement 


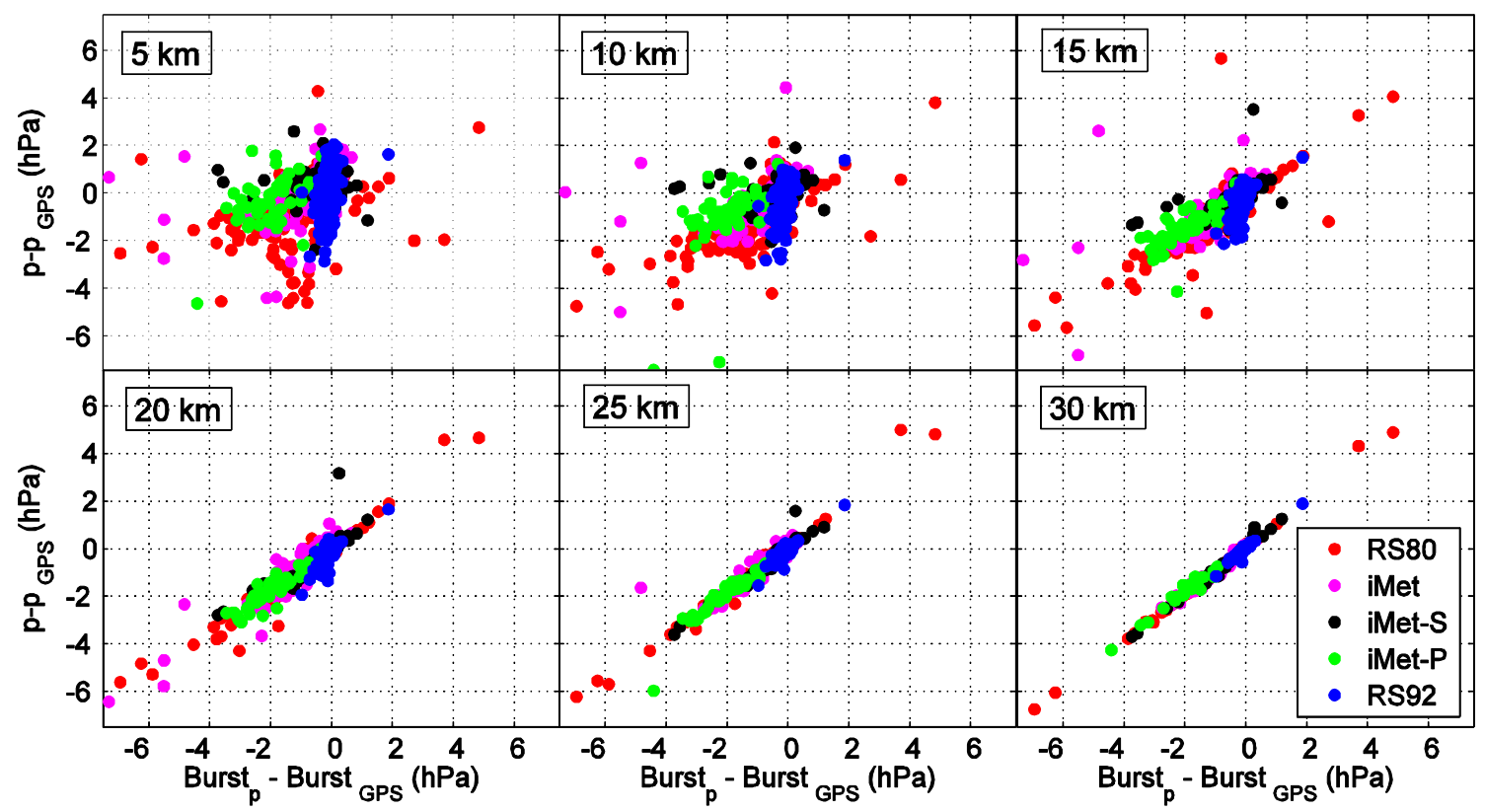

Fig. 6. Pressure offset at various altitudes versus eventual pressure offset at burst by radiosonde type. The various radiosonde types are identified by their respective colors.

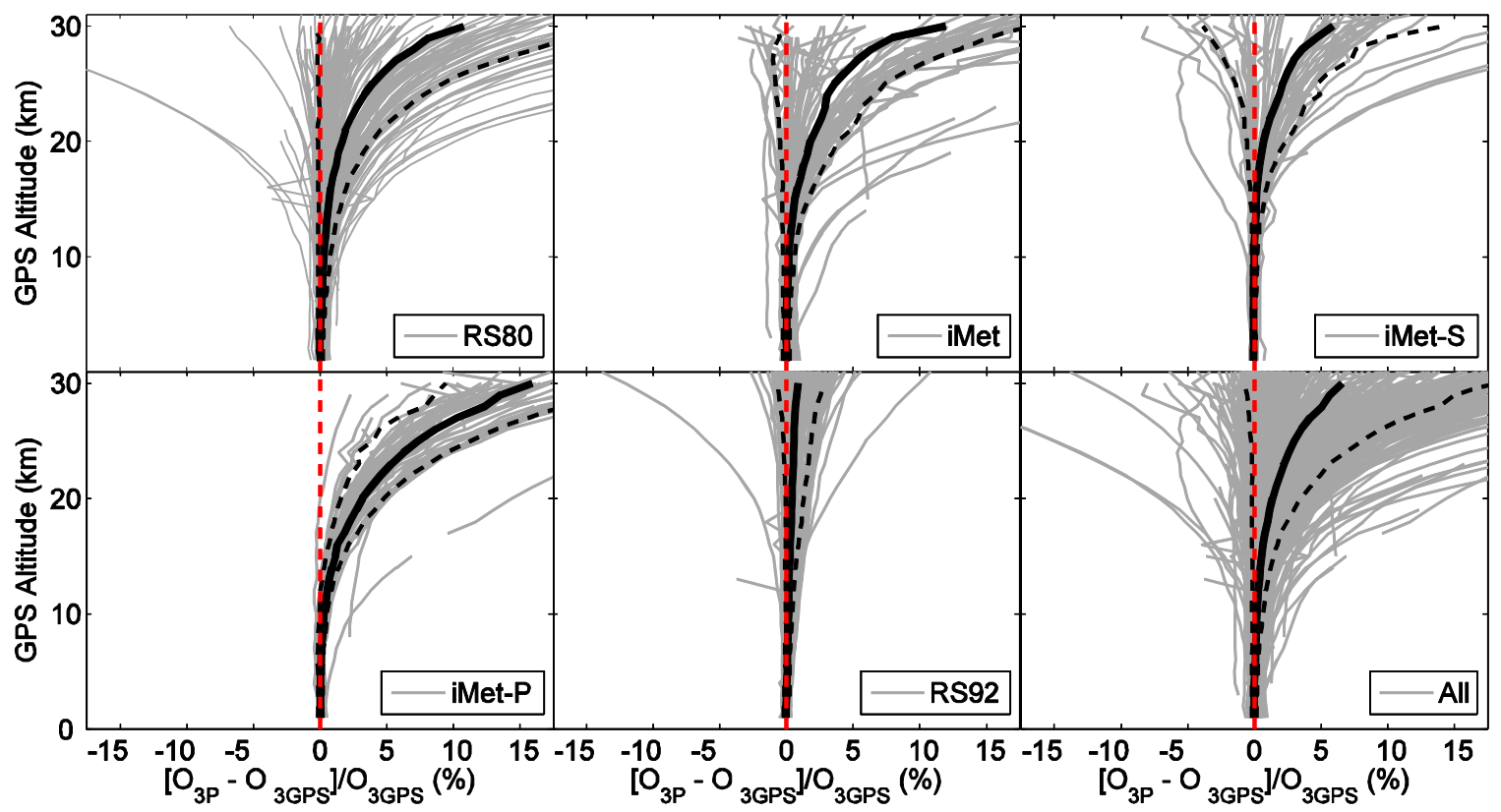

Fig. 7. Median percent $\mathrm{O}_{3 \mathrm{MR}}$ offset $\left(\left[\mathrm{O}_{3}{ }-\mathrm{O}_{3 \mathrm{GPS}}\right] / \mathrm{O}_{3 \mathrm{GPS}}\right.$ ) for every $1 \mathrm{~km}$ altitude bin from $1-30 \mathrm{~km}$ for each radiosonde type (grey). Average offsets (black solid line) for each grouping of radiosondes are shown along with 10th and 90th percentiles (black dashes). A red dashed line marks the zero line for reference.

from the iMet radiosonde 90th percentile of +3.5 DU (Table 4, Fig. 9b).

Figure 10 shows analysis of an individual profile to understand better the improved agreement in total column $\mathrm{O}_{3}$ after the pressure correction is implemented. It appears the standard $10 \mathrm{hPa}$ cut off may provide a serendipitous solution to reconciling the differences between $p$ and $p_{\text {GPS }}$ total and sonde-only column $\mathrm{O}_{3}$. The compensating effects of the pressure offset are viewed in terms of $\mathrm{O}_{3 \mathrm{MR}}, p_{\mathrm{O} 3}$, and integrated sonde-only column with $p$ and $p_{\mathrm{GPS}}$. Because $10 \mathrm{hPa}$ 

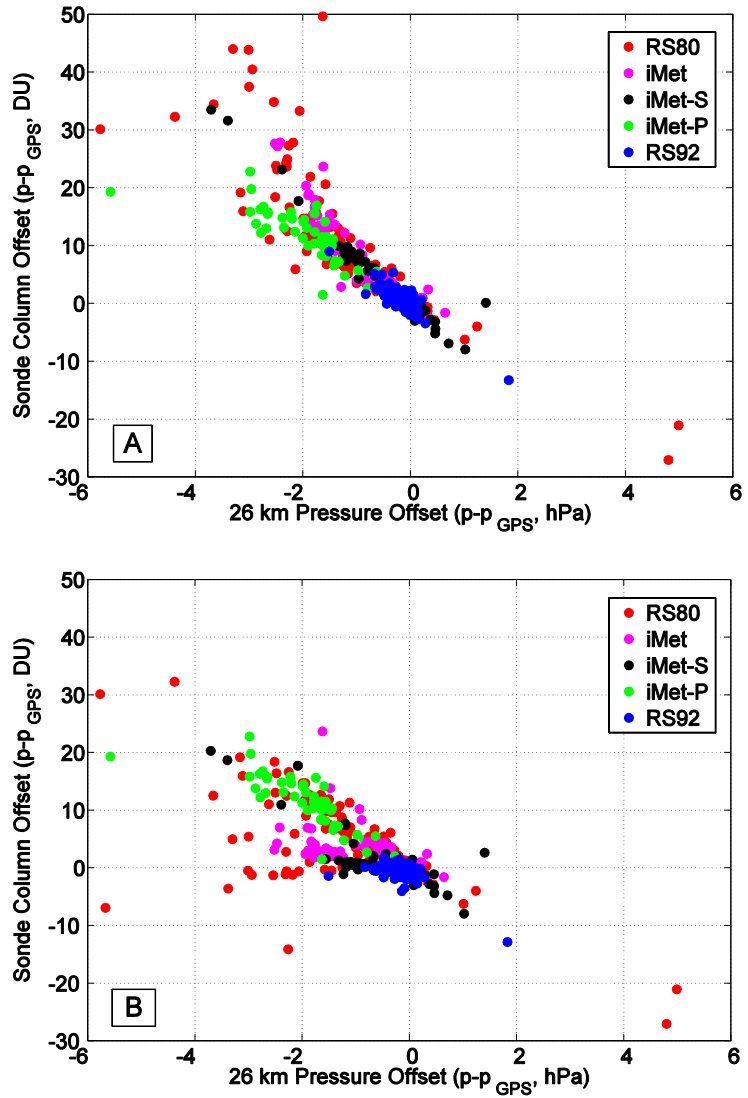

Fig. 8. Ozonesonde-only column $\mathrm{O}_{3}$ using the difference of columns calculated with $p$ and $p_{\mathrm{GPS}}$, with integration to burst (a) and cut off at $10 \mathrm{hPa}$ (b) compared to the $26 \mathrm{~km}$ pressure offset ( $p-$ $\left.p_{\mathrm{GPS}}\right)$. The various radiosonde types are identified by their respective colors. A few outliers were left from the figure for clarity.

is above the $p_{\mathrm{O} 3}$ maximum in the stratosphere, the discrepancies on either side of the $\mathrm{O}_{3}$ peak routinely compensate for one another when sonde integration is truncated (i.e., the column differences below the $\mathrm{O}_{3}$ peak are negative (positive) while above the peak they are positive (negative)). Integrating to the burst altitude for those sondes that reach above $10 \mathrm{hPa}$ results in poorer agreement with altitude - the further above $10 \mathrm{hPa}$ the sonde reaches before burst, the greater the column error becomes. Thus it appears that the $10 \mathrm{hPa}$ recommended limit for using the $\mathrm{O}_{3}$ profile data results in a fortuitous minimization of the column errors caused by the pressure offsets and therefore our analysis argues in favor of the application of an $\mathrm{O}_{3}$ climatology such as that used by McPeters and Labow (2012) above-balloon burst, with a cut off at $10 \mathrm{hPa}$ if necessary.

\section{Summary and recommendations}

A total of 731 radiosondes were compared to quantify errors in radiosonde pressure sensor measurements relative to
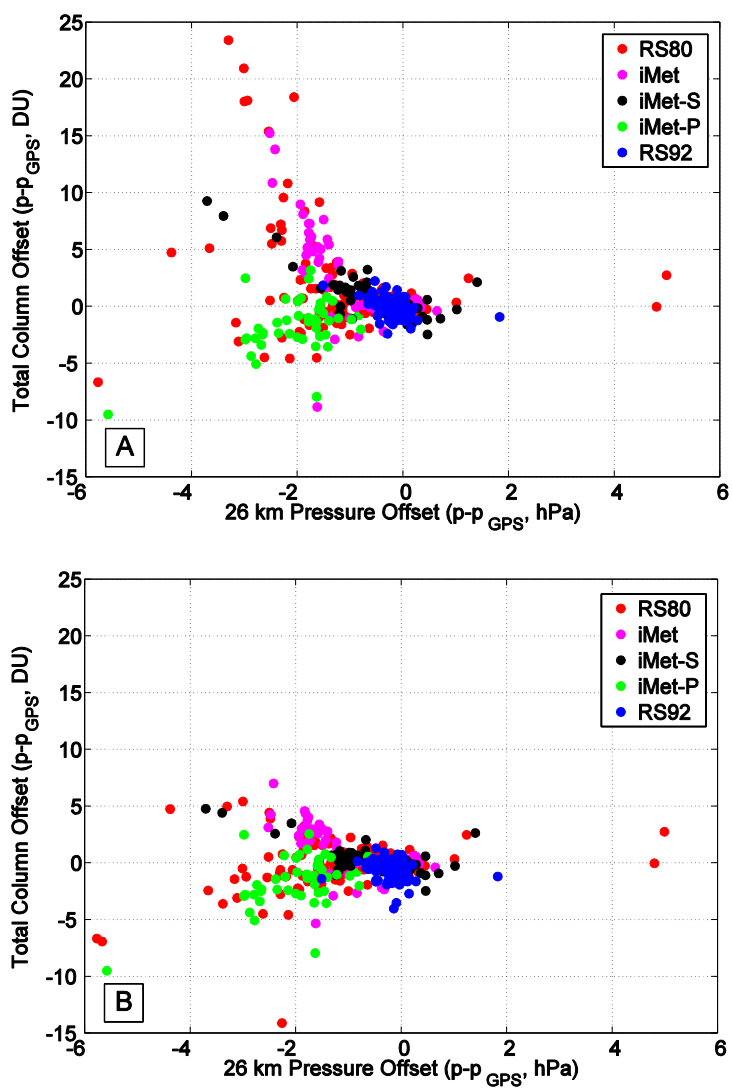

Fig. 9. As Fig. 8 except the McPeters and Labow (2012) aboveburst $\mathrm{O}_{3}$ climatology was added to each sonde from (a) burst or (b) $10 \mathrm{hPa} /$ burst if greater than $10 \mathrm{hPa}$.

pressure calculated from GPS measurements and to assess the impact these pressure offsets have on $\mathrm{O}_{3 \mathrm{MR}}$ and column $\mathrm{O}_{3}$ measurements. The pressure offset was shown to detrimentally affect $\mathrm{O}_{3}$ measurements, particularly in the stratosphere, where errors in $\mathrm{O}_{3 \mathrm{MR}}$ frequently exceed the laboratory uncertainty of the ozonesonde measurements of $\pm 5 \%$ in the lower stratosphere (Komhyr et al., 1995b). The performance of Vaisala RS92 radiosondes was superior to RS80s and three series of iMet radiosondes, and was characterized by offsets of only $\pm 0.1-0.2 \mathrm{hPa}$ at balloon burst, translating to $\mathrm{O}_{3 \mathrm{MR}}$ errors generally within $\pm 1-2 \%$ at $26 \mathrm{~km}$. The RS80 and iMet-P radiosondes had the greatest $26 \mathrm{~km}$ average offsets of -1.01 and $-1.95 \mathrm{hPa}$, respectively, translating to average $\mathrm{O}_{3 \mathrm{MR}}$ errors of -4.75 and $-8.75 \%$.

The differences between the radiosonde-measured and GPS-calculated pressures also introduced an altitude shift in the profile that must be considered for satellite validation studies and column $\mathrm{O}_{3}$ integration. The ozonesondeonly column exhibited a robust relationship with $26 \mathrm{~km}$ pressure offsets; sonde column differences between $p$ and $p_{\mathrm{GPS}}$ corrected profiles often exceeded $+10 \mathrm{DU}$, or $\sim 3 \%$ of the total column when offsets were beyond $-1.0 \mathrm{hPa}$ at $26 \mathrm{~km}$. These column differences were reduced with the application 

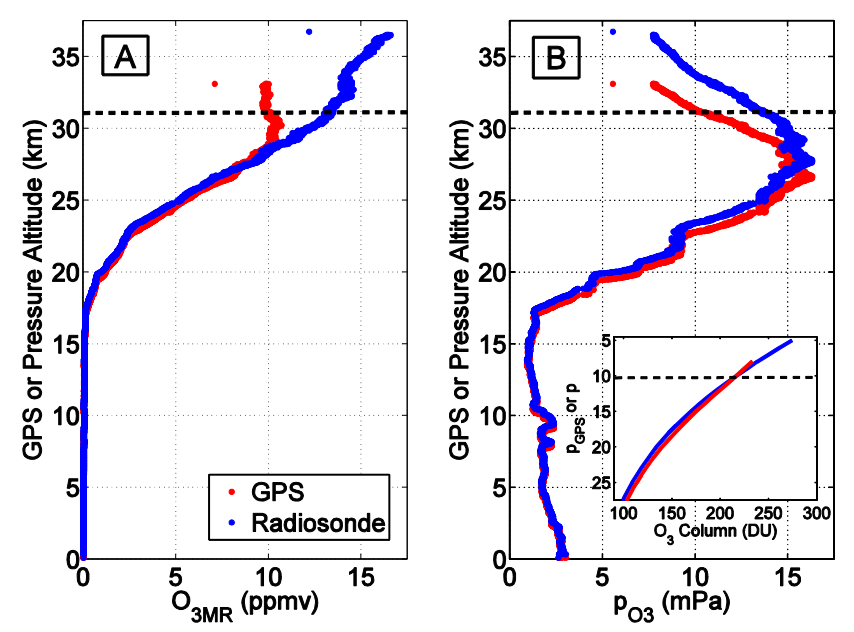

Fig. 10. Las Tablas, Panama RS80 sounding from 31 July 2007 showing GPS (red) and radiosonde (blue) profiles of $\mathrm{O}_{3 \mathrm{MR}}$ (a, left) and $p_{\mathrm{O} 3}$ (b, right). The inset in (b) is integrated ozonesonde column showing compensating differences causing agreement in column $\mathrm{O}_{3}$ by $10 \mathrm{hPa}$. The $10 \mathrm{hPa}$ cut off used prior to adding the McPeters and Labow (2012) $\mathrm{O}_{3}$ climatology is marked by the black dashed line on all plots. The median $26 \mathrm{~km}$ pressure offset for this launch is $-3.01 \mathrm{hPa}$.

of the above-balloon burst $\mathrm{O}_{3}$ climatology of McPeters and Labow (2012). When an integration cut off of $10 \mathrm{hPa}$ was applied the agreement in total column $\mathrm{O}_{3}$ between $p$ and $p_{\text {GPS }}$ profiles improved to within a few DU. The improved agreement between the uncorrected and corrected total $\mathrm{O}_{3}$ columns using a standard profile climatology and the $10 \mathrm{hPa}$ cut off argues for adopting this technique for column abundance estimates, especially with ozonesondes launched without GPS technology. Note that in the absence of GPS verification of the pressure profiles and $\mathrm{O}_{3 \mathrm{MR}}$, this cut off technique only improves the resulting calculated column abundance and does not improve the accuracy of the $\mathrm{O}_{3}$ profile shape or $\mathrm{O}_{3 \mathrm{MR}}$ profile magnitude at the top of the profile.

The ozonesonde community is currently in the process of homogenizing data (Deshler, 2012), seeking the highest accuracy trends and measurements, particularly at altitudes where satellite validation plays a vital role, from a global data set spanning dozens of stations and up to $40 \mathrm{yr}$ of measurements. The homogenization process will take into account sources of discrepancies and biases between different ozonesonde manufacturers, potassium iodide sensing solution strengths, and pump efficiency corrections. The pressure offset introduces an additional source of error (often significant) that is independent of the ozonesonde partial pressure measurement, and an error that is not constant from one flight to the next, either with altitude or within a specific radiosonde manufacturer/type. It is anticipated that the analyses here will contribute to pressure corrections required as part of the ozonesonde data reprocessing.

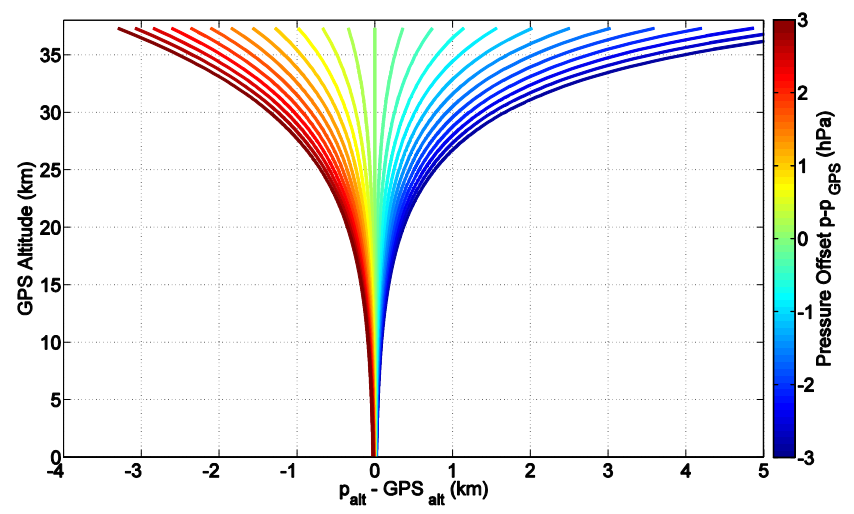

Fig. A1. Altitude differences between pressure and GPS altitude with GPS altitude based on magnitude of pressure offset. Pressure offsets from $-3 \mathrm{hPa}$ to $3 \mathrm{hPa}$ in increments of $0.25 \mathrm{hPa}$ were plotted. This calculation assumes a scale height of $\sim 7000 \mathrm{~m}\left(\bar{T}_{v}=240 \mathrm{~K}\right.$, $\left.g=g_{0}=9.80665 \mathrm{~m} \mathrm{~s}^{-2}\right)$, and was calculated from $p_{\mathrm{GPS}}=1013$ to $5 \mathrm{hPa}$.

The results of this study suggest the following recommendations regarding the pressure offset:

1. Whenever possible, ozonesondes should always be launched with a GPS-enabled radiosonde to ensure an accurate $\mathrm{O}_{3 \mathrm{MR}}$ magnitude and profile shape.

2. Pressure-dependent variables should be recalculated using $p_{\mathrm{GPS}}$, especially when pressure offsets exceed $\pm 1.0 \mathrm{hPa}$ or $\pm 5 \%$ of the total atmospheric pressure at $26 \mathrm{~km} / 20 \mathrm{hPa}$.

3. An above-burst climatology such as that used by McPeters and Labow (2012) should be applied using a $10 \mathrm{hPa}$ cut off (if applicable), particularly with ozonesondes launched prior to the GPS era for column abundance observations.

\section{Appendix A}

The effect the pressure offset has on the difference between radiosonde-reported geopotential altitude and GPS altitude is presented in Fig. A1. Using standard gravity, $g_{0}$, it is seen how a pressure offset of $\pm 1.0 \mathrm{hPa}$ (frequently observed in this study) can lead to an altitude discrepancy of \pm 1.0 $1.5 \mathrm{~km}$, having implications for column $\mathrm{O}_{3}$ and a shifting of the $\mathrm{O}_{3}$ profile shape.

The pressure offset $\left(p-p_{\mathrm{GPS}}\right)$ and $\mathrm{O}_{3 \mathrm{MR}}$ offset $\left(\left[\mathrm{O}_{3 \mathrm{MR}(p)^{-}}\right.\right.$ $\left.\mathrm{O}_{3 \mathrm{MR}(\mathrm{GPS})}\right] / \mathrm{O}_{3 \mathrm{MR}(\mathrm{GPS})}$ ) by the launch site are shown in Figs. A2 and A3. As mentioned in Sect. 3.2, similar offset groupings are observed in the campaign-based launches from Porterville, CA, Las Tablas, Panama and at Idabel and Houston which launched iMet-P sondes in the course of 10 months in 2012-2013. 


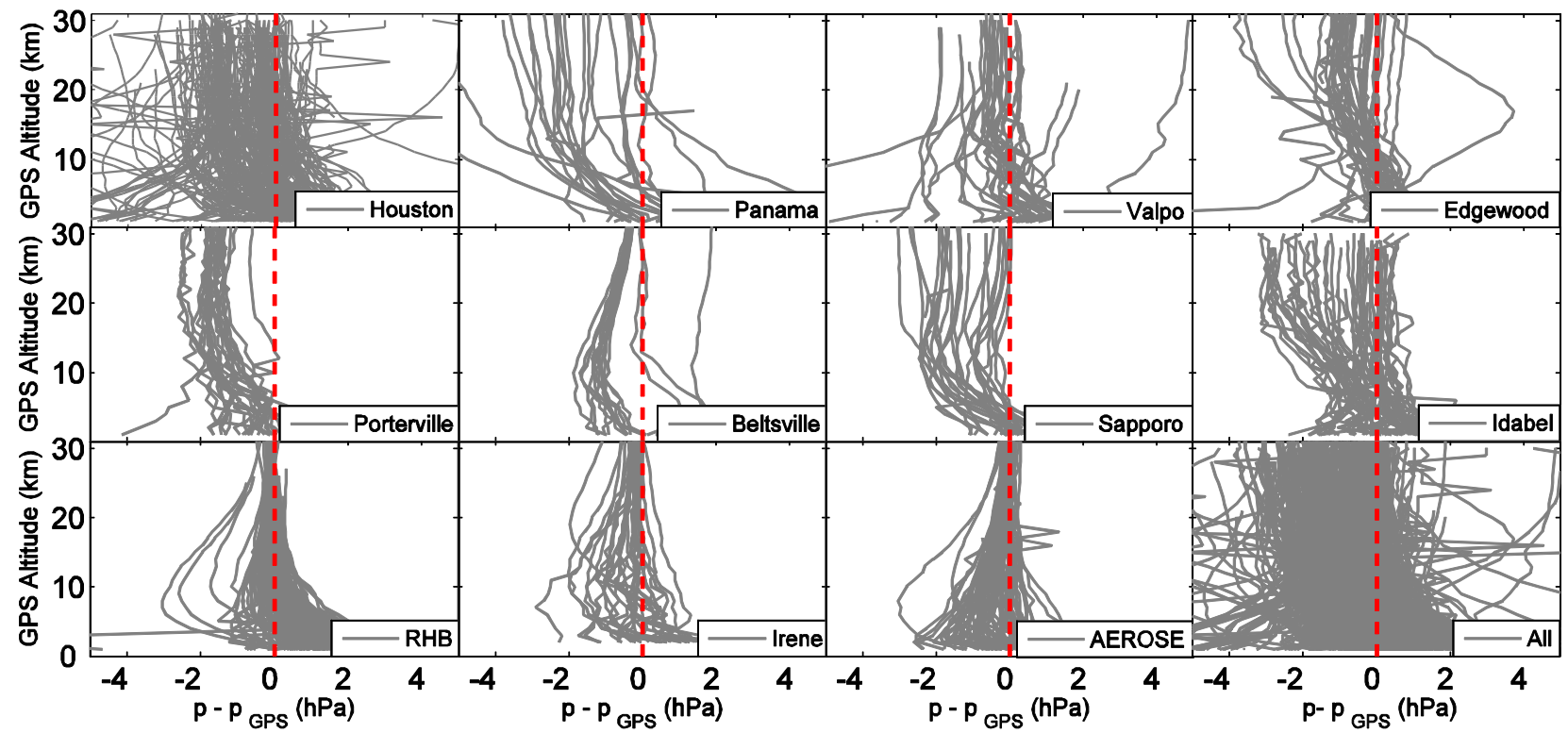

Fig. A2. Pressure offset ( $\left.p-p_{\mathrm{GPS}}\right)$ by launch site. A red dashed line marks the zero line for reference.

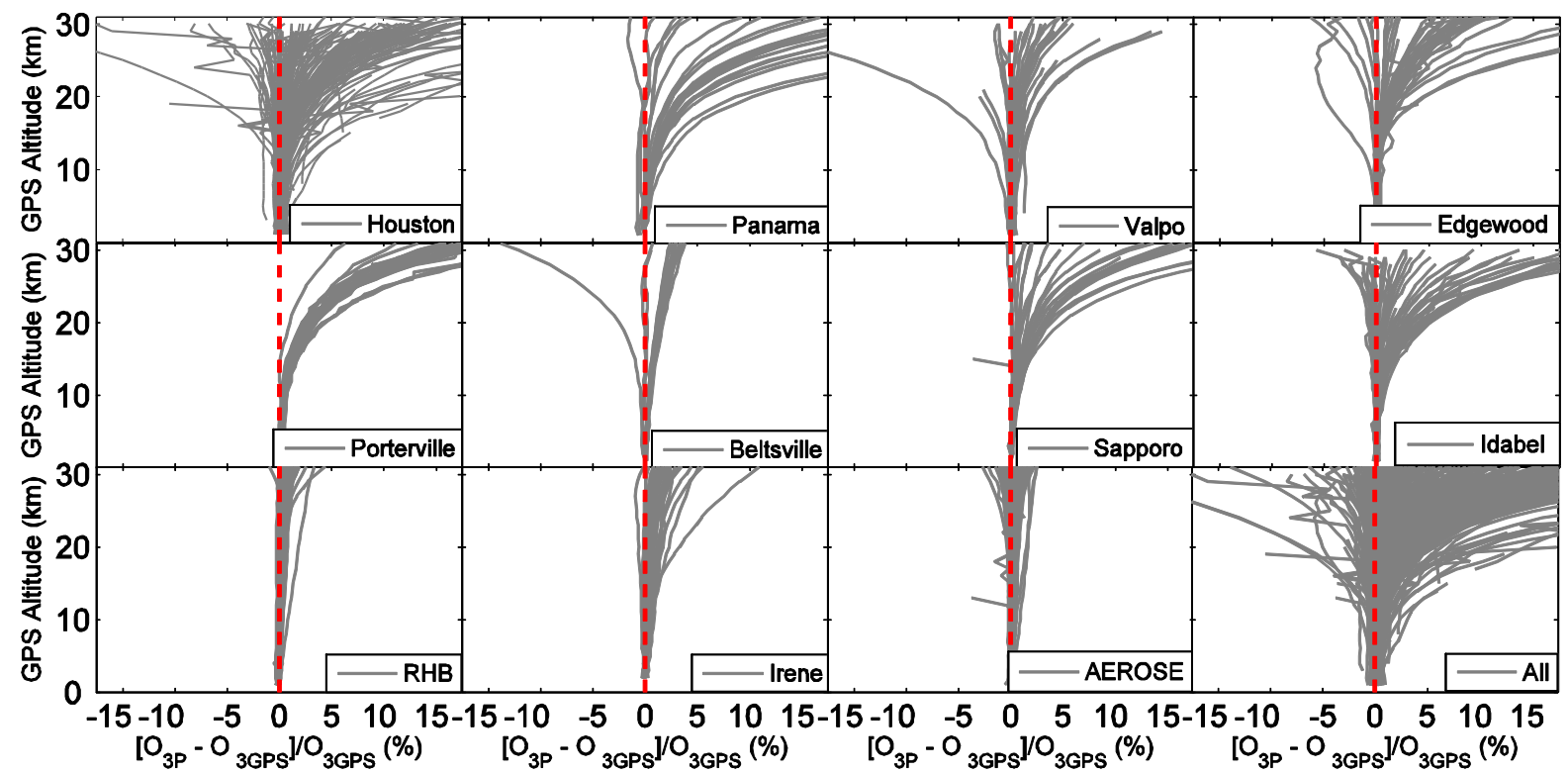

Fig. A3. Percent $\mathrm{O}_{3 \mathrm{MR}}$ offset $\left(\left[\mathrm{O}_{3}{ }^{-} \mathrm{O}_{3 \mathrm{GPS}}\right] / \mathrm{O}_{3 \mathrm{GPS}}\right)$ by launch site. A red dashed line marks the zero line for reference.

Acknowledgements. This work was supported by grants NNX09AJ236 (SHADOZ), NNX10AR39G (DISCOVERAQ), and NNX12AF056 to Penn State University with additional support to Anne Thompson from the US-South Africa Fulbright Scholar Program (2010-2011). Funding for Gary Morris was provided by a Fulbright Scholar Grant from the Japan-US. Educational Commission, NASA's Division of Earth Science Aura Data Validation Program (D. Considine and E. Hilsenrath, program managers), INTEX-B Mission, and $\mathrm{TC}^{4}$ Mission, and the Texas Commission for Environmental Quality. Original identification and analysis work for this problem began with Elizabeth Thompson at Valparaiso. Special thanks to hosts in Japan during Gary Morris' Fulbright: Jun Hirokawa and Fumio Hasebe (Hokkaido University, Sapporo, Japan) and Hajime Akimoto (Frontier Research Center for Global Change, Yokohama, Japan). Thanks also to Barry Lefer at University of Houston (Houston, TX) and Bob Heinemann at the Oklahoma State University Kiamichi Forestry Research Station (Idabel, OK) and to the many students who have been involved in the ozonesonde launches from the various sites over the years. Access to Beltsville data was facilitated by Cassie 
Stearns at the Howard University Beltsville Center for Climate Studies and Observation. Thanks to Frederick Clowney and Joe Barnes at International Met Systems for additional information and assistance. The authors would also like to thank three anonymous reviewers as well as M. Shiotani, Y. Inai, M. Fujiwara and F. Hasebe for comments which greatly improved this manuscript.

Edited by: R. Eckman

\section{References}

da Silveira, R. B., Fisch, G. F., Machado, L. A. T., Dall'Antonia, A. M., Sapucci, L. F., Fernandes, D., Marques, R., and Nash, J.: WMO intercomparison of GPS radiosondes, Alcantara, Brazil, 20 May-10 June, 2001, WMO/TD-No. 1314, 65 pp., available at: http://www.wmo.int/pages/prog/www/IMOP/publications/ IOM-90_RSO-Brazil/IOM-90_RSO_EMA_Alcantara2001.pdf, 2006.

De Muer, D. and De Backer, H.: The discrepancy between stratospheric ozone profiles from balloon soundings and from other techniques: A possible explanation, Proceedings of the Quadrennial Ozone Symposium 1992 NASA Conf. Publ. 3266, 815-818, 1992.

Deshler, T.: Transfer functions for SPC6A-ENSCI-SST1\% and SST0.5\%, available at: http://www-das.uwyo.edu/ deshler/ NDACC_O3Sondes/O3s_DQA/O3S-DQA-8.1.2_sst1_vs_sst0. 5\\&spc_vs_ensci.pdf, (last access: 25 July 2013), 2012.

Deshler, T., Mercer, J. L., Smit, H. G. J., Stubi, R., Levrt, G., Johnson, B. J., Oltmans, S. J., Kivi, R., Thompson, A. M., Witte, J. C., Davies, J., Schmidlin, F. J., Brothers, G., and Sasaki, T.: Atmospheric comparison of electrochemical cell ozonesondes from different manufacturers, and with different cathode solution strengths: The Balloon Experiment on Standards for Ozonesondes, J. Geophys. Res., 113, D04307, doi:10.1029/2007JD008975, 2008.

Dobson, G. M. B.: Atmospheric ozone and the movement of air in the stratosphere, Pure Appl. Geophys., 106-108, 1520-1530, doi:10.1007/BF00881102, 1973.

Froidevaux, L., Read, W. G., Lungu, T. A., Cofield, R. E., Fishbein, E. F., Flower, D. A., Jarnot, R. F., Ridenoure, B. P., Shippony, Z., Waters, J. W., Margitan, J. J., McDermid, I.S., Stachnik, R. A., Peckham, G. E., Braathen, G., Deshler, T., Fishman, J., Hofmann, D. J., and Oltmans, S. J.: Validation of UARS Microwave Limb Sounder ozone measurements, J. Geophys. Res., 101, 10017-10060, doi:10.1029/95JD02325, 1996.

Gaffen, D. J.: Temporal inhomogeneities in radiosonde temperature records, J. Geophys. Res., 99, 3667-3676, doi:10.1029/93JD03179, 1994.

Gaffen, D. J., Sargent, M. A., Habermann, R. E., and Lanzante, J. R.: Sensitivity of tropospheric and stratospheric temperature trends to radiosonde data quality, J. Climate, 13, 1776-1796, doi:10.1175/1520-0442(2000)013<1776:SOTAST>2.0.CO;2, 1999.

Hurst, D. F., Hall, E. G., Jordan, A. F., Miloshevich, L. M., Whiteman, D. N., Leblanc, T., Walsh, D., Vömel, H., and Oltmans, S. J.: Comparisons of temperature, pressure and humidity measurements by balloon-borne radiosondes and frost point hygrometers during MOHAVE-2009, Atmos. Meas. Tech., 4, 2777-2793, doi:10.5194/amt-4-2777-2011, 2011.
Inai, Y., Hasebe, F., Shimizu, K., and Fujiwara, M.: Correction of radiosonde pressure and temperature measurements using simultaneous GPS height data, SOLA, 5, 109-112, doi:10.2151/sola.2009-028, 2009.

IPCC (Intergovernmental Panel on Climate Change): Climate Change 2007: The Physical Science Basis, Contribution of Working Group I to the Fourth Assessment Report of the Intergovernmental Panel on Climate Change, edited by: Solomon, S., Qin, D., Manning, M., Chen, Z., Marquis, M., Averyt, K. B., Tignor, M., and Miller, H. L., Cambridge University Press, Cambridge, United Kingdom and New York, NY, USA, 996 pp., 2007.

Jiang, Y. B., Froidevaux, L., Lambert, A., Livesey, N. J., Read, W. G., Waters, J. W., Bojkov, B., Leblanc, T., McDermid, I. S., Godin-Beekmann, S., Filipiak, M. J., Harwood, R. S., Fuller, R. A., Daffer, W. H., Drouin, B. J., Cofield, R. E., Cuddy, D. T., Jarnot, R. F., Knosp, B. W., Perun, V. S., Schwartz, M. J., Snyder, W. V., Stek, P. C., Thurstans, R. P., Wagner, P. A., Allaart, M., Andersen, S. B., Bodeker, G., Calpini, B., Claude, H., Coetzee, G., Davies, J., De Backer, H., Dier, H., Fujiwara, M., Johnson, B., Kelder, H., Leme, N. P., König-Langlo, G., Kyro, E., Laneve, G., Fook, L. S., Merrill, J., Morris, G., Newchurch, M., Oltmans, S., Parrondos, M. C., Posny, F., Schmidlin, F., Skrivankova, P., Stubi, R., Tarasick, D., Thompson, A., Thouret, V., Viatte, P., Vömel, H., von Der Gathen, P., Yela, M., and Zablocki, G.: Validation of Aura Microwave Limb Sounder ozone by ozonesonde and lidar measurements, J. Geophys. Res., 112, D24S34, doi:10.1029/2007JD008776, 2007.

Johnson, B. J., Oltmans, S. J., Vömel, H., Smit, G. J., Deshler, T., and Kröger, C.: Electrochemical concentration cell (ECC) ozonesonde pump efficiency measurements and tests on the sensitivity to ozone of buffered and unbuffered ECC sensor cathode solutions, J. Geophys. Res., 107, 4393, doi:10.1029/2001JD000557, 2002.

Komhyr, W. D.: Electrochemical concentration cells for gas analysis, Ann. Geophys., 25, 203-210, 1969, http://www.ann-geophys.net/25/203/1969/.

Komhyr, W. D., Connor, B. J., McDermid, I. S., McGee, T. J., Parrish, A. D., and Margitan, J. J.: Comparison of STOIC groundbased lidar, microwave spectrometer, and Dobson spectrophotometer Umkehr ozone profiles with ozone profiles from balloonborne electrochemical concentration cell ozonesondes, J. Geophys. Res., 100, 9273-9282, doi:10.1029/94JD02173, 1995a.

Komhyr, W. D., Barnes, R. A., Brothers, G. B., Lathrop, J. A., and Opperman, D. P.: Electrochemical concentration cell ozonesonde performance evaluation during STOIC 1989, J. Geophys. Res., 100, 9231-9244, doi:10.1029/94JD02175, 1995 b.

Kroon, M., de Haan, J. F., Veefkind, J. P., Froidevaux, L., Wang, R., Kivi, R., and Hakkarainen, J. J.: Validation of operation ozone profiles from the Ozone Monitoring Instrument, J. Geophys. Res., 116, D18305, doi:10.1029/2010JD015100, 2011.

Liu, X., Chance, K., Sioris, C. E., Kurosu, T. P., and Newchurch, M. J.: Intercomparison of GOME, ozonesonde, and SAGE II measurementsof ozone: Demonstration of the need to homogenize available ozonesonde data sets, J. Geophys. Res., 111, D14305, doi:10.1029/2005JD006718, 2006.

Logan, J. A.: Trends in the vertical distribution of ozone: An analysis of ozonesonde data, J. Geophys. Res., 99, 25553-25585, doi:10.1029/94JD02333, 1994. 
Logan, J. A., Megretskaia, I. A., Miller, A. J., Tiao, G. C., Choi, D., Zhang, L., Stolarski, R. S., Labow, G. J., Hollandsworth, S. M., Bodeker, G. E., Claude, H., De Muer, D., Kerr, J. B., Tarasick, D. W., Oltmans, S. J., Johnson, B. J., Schmidlin, F., Staehelin, J., Viatte, P., and Uchino, O.: Trends in the vertical distribution of ozone: A comparison of two analyses of ozonesonde data, J. Geophys. Res., 104, 26373-26399, doi:10.1029/1999JD900300, 1999.

Logan, J. A., Staehelin, J., Megretskaia, I. A., Cammas, J.-P., Thouret, V., Claude, H., De Backer, H., Steinbacher, M., Scheel, H.-E., Stübi, R., Fröhlich, M., and Derwent, R.: Changes in ozone over Europe: Analysis of ozone measurements from sondes, regular aircraft (MOZAIC) and alpine surface sites, J. Geophys. Res., 117, D09301, doi:10.1029/2011JD016952, 2012.

McPeters, R. D. and Labow, G. J.: Climatology 2011: An MLS and sonde derived ozone climatology for satellite retrieval algorithms, J. Geophys. Res., 117, D10303, doi:10.1029/2011JD017006, 2012.

McPeters, R. D., Labow, G. J., and Johnson, B. J.: A satellitederived ozone climatology for balloonsonde estimation of total column ozone, J. Geophys. Res., 102, 8875-8885, doi:10.1029/96JD02977, 1997.

McPeters, R. D., Labow, G. J., and Logan, J. A.: Ozone climatological profiles for satellite retrieval algorithms, J. Geophys. Res., 112, D05308, doi:10.1029/2005JD006823, 2007.

Miloshevich, L. M., Vömel, H., Whiteman, D. N., Lesht, B. M., Schmidlin, F. J., and Russo, F.: Absolute accuracy of water vapor measurements from six operational radiosonde types launched during AWEX-G and implications for AIRS validation, J. Geophys. Res., 111, D09S10, doi:10.1029/2005JD006083, 2006.

Miller, A. J., Tiao, G. C., Reinsel, G. C., Wuebble, D., Bishop, L., Kerr, J., Nagatani, R. M., DeLuisi, J. J., and Mateer, C. L.: Comparisons of observed ozone trends in the stratosphere through examination of Umkehr and balloon ozonesonde data, J. Geophys. Res., 100, 11209-11217, doi:10.1029/95JD00632, 1995.

Morris, G. A., Labow, G., Akimoto, H., Takigawa, M., Fujiwara, M., Hasebe, F., Hirokawa, J., and Koide, T.: On the use of the correction factor with Japanese ozonesonde data, Atmos. Chem. Phys., 13, 1243-1260, doi:10.5194/acp-13-1243-2013, 2013.

Nalli, N. R., Barnet, C. D., Reale, A., Tobin, D., Gambacorta, A., Maddy, E. S., Joseph, E., Sun, B., Borg, L., Mollner, A. K., Morris, V. R., Liu, X., Divakarla, M., Minnett, P. J., Knuteson, R. O., King, T. S., and Wolf, W. W.: Validation of satellite sounder Environmental Data Records: Application to the Cross-track Infrared Microwave Sounder Suite (CrIMSS), J. J. Geophys. Res. Atmos., 118, 1-16, doi:10.1002/2013JD020436, 2013.

Nash, J., Smout, R., Oakley, T., Pathack, B., and Kurnosenko, S.: WMO intercomparison of high quality radiosonde systems, Vacoas, Mauritius, 02 - 25 February 2005, WMO/TD-No. 1303, 115 pp., available at: http://www.wmo.int/pages/prog/ www/IMPO/publications/IOM-83_RSO-Mauritius/IOM-83_ Radiosondes_Vacoas2005.pdf (last access: 12 July 2013), 2006.

Nash, J., Oakley, T., Vömel, H., and Wei, L.: WMO intercomparison of high quality radiosonde systems, Yangjiang, China, 12 July-3 August 2010, WMO/TD-No. 1580, 248 pp., available at: http://www.wmo.int/pages/prog/www/IMOP/ publications-IOM-series.html (last access: 8 November 2013) 2011.
National Imagery and Mapping Agency Technical Report: Department of Defense World Geodetic System 1984, available at: http://earth-info.nga.mil/GandG/publications/tr8350.2/ wgs84fin.pdf (last access: 8 November 2013), 2000.

Osterman, G. B., Kulawik, S. S., Worden, H. M., Richards, N. A. D., Fisher, B. M., Eldering, A., Shephard, M. W., Froidevaux, L., Labow, G., Luo, M., Herman, R. L., Bowman, K. W., and Thompson, A. M.: Validation of Tropospheric Emission Spectrometer (TES) measurements of the total, stratospheric, and tropospheric column abundance of ozone, J. Geophys. Res., 113, D15S16, doi:10.1029/2007JD008801, 2008.

Rault, D. F. and Taha, G.: Validation of ozone profiles retrieved from Stratospheric Aerosol and Gas Experiment II limb scatter measurements, J. Geophys. Res., 112, D13309, doi:10.1029/2006JD007679, 2007.

Richner, H. and Viatte, P.: The hydrostatic equation in the evaluation algorithm for radiosonde data, J. Atmos. Ocean. Tech., 12, 649656, 1995.

Smit, H. G. J. and Berg, M.: JOSIE-2009/2010 experiments with ECC-ozone sonde types using different sensing solutions: The need for empirical transfer functions to resolve inhomogenities in time series, available at: http://igaco-o3.fmi.fi/VDO/ presentations_2011/ground-based/WS_2011_Smit.pdf (last access: 25 July 2013), 2011.

Smit, H. G. J. and Kley, D.: JOSIE: The 1996 WMO International intercomparison of ozonesondes under quasi flight conditions in the environmental simulation chamber at Jülich, WMO Global Atmosphere Watch report series, No. 130 (Technical Document No. 926), World Meteorological Organization, Geneva, 1998.

Smit, H. G. J., Straeter, W., Johnson, B. J., Oltmans, S. J., Davies, J., Tarasick, D. W., Hoegger, B., Stubi, R., Schmidlin, F. J., Northam, T., Thompson, A. M., Witte, J. C., Boyd, I., and Posny, F.: Assessment of the performance of ECC-ozonesondes under quasi-flight conditions in the environmental simulation chamber: Insights from the Juelich Ozone Sonde Intercomparison Experiment (JOSIE), J. Geophys. Res. Atmos., 112, D19306, doi:10.1029/2006JD007308, 2007.

Smit, H. G. J, Oltmans, S., Deshler, T., Tarasick, D., Johnson, B., Schmidlin, F., Stuebi, R., and Davies, J.: SI2N/O3SDQA Activity: Guide lines for homogenization of ozone sonde data, available at: http://das.uwyo.edu/ deshler/ NDACC_O3Sondes/O3s_DQA/O3S-DQA-Guidelines\%

20Homogenization-V2-19November2012.pdf (last access: 8 November, 2013), 2012.

Steinbrecht, W., Claude, H., Schönenborn, F., Leiterer, U., Dier, H., and Lanzinger, E.: Pressure and temperature differences between Vaisala RS80 and RS92 radiosonde systems, J. Atmos. Ocean. Tech., 25, 909-927, doi:10.1175/2007JTECHA999.1, 2008.

Sun, B., Reale, A., Seidel, D. J., and Hunt, D. C.: Comparing radiosonde and COSMIC atmospheric profile data to quantify differences among radiosonde types and the effects of imperfect collocation on comparison statistics, J. Geophys. Res., 115, D23104, doi:10.1029/2010JD014457, 2010.

Thompson, A. M., Witte, J. C., McPeters, R. D., Oltmans, S. J., Schmidlin, F. J., Logan, J. A., Fujiwara, M., Kirchhoff, V. W. J. H., Posny, F., Coetzee, G. J. R., Hoegger, B., Kawakami, S., Ogawa, T., Johnson, B. J., Vömel, H., and Labow, G.: Southern Hemisphere Additional Ozonesondes (SHADOZ) 19982000 tropical ozone climatology: 1. Comparison with TOMS 
and ground-based measurements, J. Geophys. Res., 108, 8238, doi:10.1029/2001JD000967, 2003.

Thompson, A. M., Witte, J. C., Smit, H. G. J., Oltmans, S. J., Johnson, B. J., Kirchhoff, V. W. J. H., and Schmidlin, F. J.: Southern Hemisphere Additional Ozonesondes (SHADOZ) 1998-2004 tropical ozone climatology: 3. Instrumentation, station-to-station variability, and evaluation with simulated flight profiles, J. Geophys. Res., 112, D03304, doi:10.1029/2005JD007042, 2007.

Vömel, H., Selkirk, H., Miloshevich, L., Valverde-Canossa, J., Valdés, J., Kyrö, E., Kivi, R., Stolz, W., Peng, G., and Diaz, J. A.: Radiation dry bias of the Vaisala RS92 humidity sensor, J. Atmos. Ocean. Tech., 24, 953-962, doi:10.1175/JTECH2019.1, 2007.
WMO (World Meteorological Organization): Scientific Assessment of Ozone Depletion: 2010, Global Ozone Research and Monitoring Project - Report No. 52, 516 pp., Geneva, Switzerland, 2011.

WMO (World Meteorological Organization): Quality Assurance and Quality Control for Ozonesonde Measurements in GAW, Global Atmospheric Watch - Report No. 201, 100 pp., Geneva, Switzerland, available at: http://www.wmo.int/pages/prog/arep/ gaw/documents/GAW_201.pdf, 2013.

Yoneyama, K., Fujita, M., Sato, N., Fujiwara, M., Inai, Y., and Hasebe, F.: Correction for radiation dry bias found in RS92 radiosonde data during the MISMO field experiment, SOLA, 4, 13-16, doi:10.2151/sola.2008-004, 2008. 